\title{
Der Vier-Kammer-Blick in der fetalen Echokardiografie
}

\author{
C. Berg, A. Geipel, U. Gembruch
}

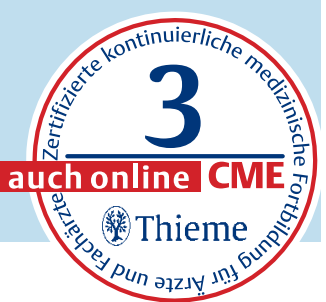

Abteilung für Geburtshilfe und Pränatale Medizin, Universitätsklinikum Bonn

eingereicht 11.2 .2007

akzeptiert $\quad 2.3 .2007$

Bibliografie

DOI 10.1055/s-2007-963085 Ultraschall in Med 2007; 28:

132-157 @ Georg Thieme

Verlag KG Stuttgart · New York . ISSN 0172-4614

Korrespondenzadresse

Priv.-Doz. Dr. Christoph Berg

Abteilung für Geburtshilfe und

Pränatale Medizin, Universitätsklinikum Bonn

Sigmund-Freud-Str. 25

53105 Bonn

Tel.: ++49/228/28715942

Fax: $++49 / 228 / 28716088$

Christoph.Berg@ukb.uni-

bonn.de

\section{Lernziele}

$\nabla$

- Bedeutung des Vier-Kammer-Blickes beim Screening auf Herzfehler.

- Technische Grundlagen.

- Einstellung des Vier-Kammer-Blickes.

- Physiologische Befunde im Vier-KammerBlick.

- Auffälligkeiten im Vier-Kammer-Blick.

- Herzfehler, die im Vier-Kammer-Blick diagnostiziert werden können.

- Herzfehler, die im Vier-Kammer-Blick nicht diagnostiziert werden können.

- Vier-Kammer-Blick im ersten Trimenon.

\section{Einleitung}

$\nabla$

Herzfehler können isoliert, aber auch in Kombination mit nicht-chromosomal und chromosomal bedingten extrakardialen Fehlbildungen auftreten. Mit einer Inzidenz von 6-8/1000 Lebendgeborenen und von ca. 10/1000 Feten im 2. Trimenon gehören sie nicht nur zu den häufigsten Fehlbildungen, sondern weisen auch eine besonders hohe Mortalität und Morbidität auf; rund $20 \%$ der Todesfälle in der Neonatalzeit bzw. 50\% der Todesfälle infolge angeborener Fehlbildungen im ersten Lebensjahr sind auf die kritischen und schweren Herzfehler zurückzuführen [1].

Gerade bei den kritischen Herzfehlern scheint es offensichtlich, dass nach einer bereits pränatal gestellten Diagnose durch die so mögliche Optimierung des perinatalen Managements (Wahl des Entbindungsortes, Offenhalten der fetalen Shunts etc.) die präoperative Morbidität (metabolische Azidose, Niereninsuffizienz, Multiorganversagen, Reanimationspflichtigkeit) und Mortalität gesenkt werden können. Mittlerweile konnte der Vorteil der pränatalen Diagnose für das kindliche Outcome auch in verschiedenen Studien belegt werden, insbesondere für das hy- poplastische Linksherz, die Transposition der großen Arterien und die schwere Aortenisthmusstenose [2, 3].

Es sind gerade die Kinder mit Herzfehlern, die am meisten durch eine Verbesserung ihres Outcome von einer bereits pränatal erfolgten Diagnostik profitieren, im Gegensatz zu vielen anderen Anomalien, bei denen die pränatale Diagnose das Outcome nicht entscheidend ändert bzw. gar zu einer Schwangerschaftsunterbrechung führt. Eine neue Perspektive für schwere Links- und auch Rechtsherzobstruktionen eröffnet die intrauterine Ballondilatation mit dem Ziel, eine weitere Verschlechterung der Ventrikelfunktion zu vermeiden und so eine biventrikuläre Korrekturoperation zu ermöglichen [4]. Neben dieser Verbesserung des Outcome sind auch die anderen an ein Screening gestellten Forderungen (hohe Prävalenz und Schwere der Erkrankung, einfache und sichere Screening-Methode, Validität und Kosteneffektivität) bei der Diagnostik fetaler Herzfehler erfüllt. Da aber nur 20\% der Herzfehler bei Feten auftreten, die ein entsprechendes Risiko aufweisen, kann das Ziel der allgemeinen pränatalen Entdeckung der schweren isolierten Herzfehler bei den restlichen $80 \%$ der Neugebornen nur durch eine Untersuchung aller Feten erreicht werden [1]. Zwar wäre es wünschenswert, bei allen Feten eine detaillierte fetale Echokardiografie mit entsprechend hohen Entdeckungsraten durchzuführen, doch sind die Ressourcen hierzu derzeit nicht vorhanden.

Vielmehr bietet es sich an, die Untersuchung des Vier-Kammer-Blickes (4KB) in das allgemeine Ultraschallscreening aufzunehmen das bereits in fast allen Ländern Europas um die 20. SSW herum durchgeführt wird [5]. Dementsprechend beinhalten auch die Qualitätsanforderungen an die geburtshilfliche Ultraschalldiagnostik (DEGUM-Stufe I) die Darstellung des 4KB [6]. 


\section{The Four-Chamber View in Fetal Echocardiography}

C. Berg, A. Geipel, U. Gembruch

Department of Obstetrics and Prenatal Medicine, University Hospital, Bonn

\section{Training Targets}

$\nabla$

Value of the four-chamber view in screening for cardiac defects.

- Technical principles.

- Aquisition of the four-chamber view.

- Physiological findings in the four-chamber view.

- Conspicuous findings in the four-chamber view.

- Cardiac defects that can be diagnosed in the four-chamber view.

- Cardiac defects that cannot be diagnosed in the four-chamber view.

- Four-chamber view in the first trimester.

\section{Introduction}

$\nabla$

Cardiac abnormalities can occur not only as isolated entities but also in combination with extracardiac malformations of non-chromosomal or chromosomal origin. With an incidence of $6-8 / 1000$ live births and about $10 / 1000$ fetuses in the second trimester, they belong not only to the most frequent malformations but also exhibit a particularly high mortality and morbidity. About $20 \%$ of deaths in the neonatal period or, respectively, $50 \%$ of the deaths due to congenital malformations in the first year of life can be attributed to critical and severe cardiac abnormalities [1].

Particularly in the case of critical heart defects it seems clear that, after diagnosis in the prenatal period and the thus possible optimisation of the perinatal management (choice of hospital for delivery, keeping the fetal shunts open etc.), preoperative morbidity (metabolic acidosis, renal insufficiency, multiorgan failure, need for reanimation) and mortality can be reduced. In the mean time the advantages of prenatal diagnosis for the baby's outcome have been de- monstrated in various studies, in particular for hypoplastic left heart, transposition of the great arteries and coarctation of the aorta [2, 3]. It is just those children with heart defects who profit most by an improvement of their outcome from diagnostics carried out in the prenatal period, in contrast to many other anomalies for which prenatal diagnosis does not affect the outcome decisively or even leads to termination of the pregnancy. Intrauterine balloon dilatation with the objective of avoiding a further deterioration of ventricular function and making a biventricular corrective operation possible opens up new perspectives for severe left and also right heart obstructions [4].

Besides these improvements in outcome, the other requirements of a screening method (high prevalence and severity of the disease, simple and safe screening method, validity and cost-effectiveness) are fulfilled by the diagnostics for fetal heart defects. Since only about $20 \%$ of the heart defects occur in fetuses exhibiting a corresponding risk factor, the objective of a global detection of severe isolated heart defects in the remaining $80 \%$ of the new-born babies can only be achieved by an examination of all fetuses [1]. Although it would be desirable to carry out detailed echocardiography in all fetuses with a correspondingly high detection rate, the necessary resources are currently not available.

Instead it would be reasonable to include an examination of the four-chamber view (4CV) in the general sonographic screening that is carried out at around the $20^{\text {th }}$ week of pregnancy in practically all European countries [5]. Accordingly, the quality requirements for basic obstetric sonographic diagnostics (DEGUM Step I) also include acquisition of the 4CV [6].

In the framework of the screening program it is found that the detection rate correlates strongly with the experience of the respective examiner. Thus, continuing and structured training and fur-

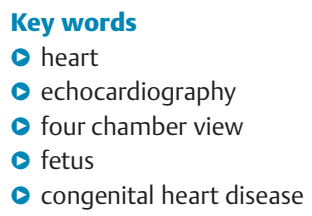

received 11.2.2007 accepted 2.3.2007

\section{Bibliography}

Dol 10.1055/s-2007-963085 Ultraschall in Med 2007; 28 :

132-157 @ Georg Thieme Verlag KG Stuttgart · New York · ISSN 0172-4614

\section{Correspondence}

Priv.-Doz. Dr. Christoph Berg Department of Obstetrics and Prenatal Medicine, University Hospital, Bonn

Sigmund-Freud-Str. 25 53105 Bonn

Tel.: ++49/228/28715942

Fax: $++49 / 228 / 28716088$

Christoph.Berg@ukb.unibonn.de 


\begin{tabular}{|c|c|c|c|c|c|c|}
\hline & Inzidenz (pro 1000) & Risiko & Untersuchung & Ssw & Erfahrung & Sensitivität \\
\hline Buskens et al. 1996 & 8 & niedrig & $4 \mathrm{~KB}$ & $16-24$ & Stufe 1 & $5 \%$ \\
\hline Todros et al. 1997 & 4,8 & niedrig & $4 K B$ & $18-22$ & Stufe 1 & $15 \%$ \\
\hline \multirow[t]{2}{*}{ Tegnander et al. 2006} & 3 (nur kritische CHD) & niedrig & nur $4 \mathrm{~KB}$ & $16-22$ & Stufe $1-2$ & $39 \%$ \\
\hline & & & 4KB+Ausflusstrakt & & & $57 \%$ \\
\hline Hafner et al. 1998 & 13 & niedrig & $4 \mathrm{~KB}+$ Ausflusstrakt & $16-22$ & Stufe 2 & $44 \%$ \\
\hline Ogge et al. 2006 & 9,1 & niedrig & $4 \mathrm{~KB}+$ Ausflusstrakt & $>18$ & Stufe 2 & $66 \%$ \\
\hline \multirow[t]{2}{*}{ Wong et al. 2003} & 7 & niedrig & 4KB+Ausflusstrakt & $17-24$ & Stufe $1 / 2$ & $21 \%$ \\
\hline & & & & & Stufe 3 & $61 \%$ \\
\hline \multirow[t]{2}{*}{ Stümpflen et al. 1996} & 7 & gemischt & nur $4 K B$ & $18-28$ & Stufe 3 & $48 \%$ \\
\hline & & & $4 \mathrm{~KB}+$ Ausflusstrakt + Farbe & & & $88 \%$ \\
\hline Yagel et al. 1997 & 7,6 & gemischt & $4 K B+$ Ausflusstrakt + Farbe & $13-22$ & Stufe 3 & $81 \%$ \\
\hline
\end{tabular}

Tab. 1 Studien zum pränatalen Screening kongenitaler Herzfehler modifiziert nach [1]

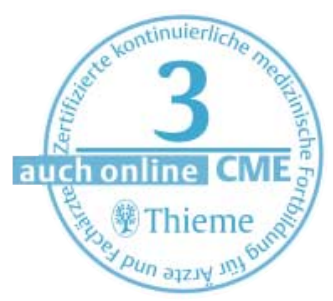

Im Rahmen der Screeningprogramme zeigt sich, dass die Entdeckungsraten stark mit der Erfahrung der jeweiligen Untersucher korrelieren. Daher sind fortwährende und strukturierte Ausbildungs- und Trainingsprogramme erforderlich, um die Möglichkeiten und Chancen des pränatalen Ultraschallscreenings allgemein und der Herzfehlerdiagnostik im Besonderen auszuschöpfen. Nicht nur die Darstellung, sondern auch die Interpretation des 4KB können durch Anleitung und ständige Übung verbessert werden, was über Jahre hinweg zu einer stetig steigenden Entdeckungsrate von Herzfehlern allein über den $4 \mathrm{~KB}$ führt $[7,8]$.

Vielfach konnte gezeigt werden, dass die schrittweise Einführung des Vier-Kammer-Blickes (4KB) in das pränatale Ultraschallscreening sowie dann auch die darüber hinausgehende Darstellung der Abganges und des Verlaufs der beiden großen Arterien zu einer deutlichen Steigerung der Entdeckungsraten führt [1]. So beinhalten die Qualitätsanforderungen an die weiterführende differenzialdiagnostische Ultraschalluntersuchung (DEGUM-Stufe II) neben dem 4KB auch die Darstellung der links- und rechtsventrikulären Ausflusstrakte [9].

Die folgenden Ausführungen sollen einen umfassenden Überblick über die Darstellung und das diagnostische Potenzial des 4KB geben; das Vorgehen bei der Einstellung des $4 \mathrm{~KB}$, die normalen Strukturen und die nachweisbaren Anomalien werden aufgezeigt, ebenso wie mögliche Fehler und Grenzen des 4KB bei der Diagnostik fetaler Herzfehler. Neben der Strukturanalyse im zweidimensionalen Bild wird auch der Einsatz der Farbdoppler-Sonografie bei der Beurteilung des $4 \mathrm{~KB}$ bzw. der Diagnose der jeweiligen Herzfehler dargelegt, da heutzutage die meisten Ultraschallgeräte bereits über diese Technik verfügen.

\section{Stellenwert des Vier-Kammer-Blickes beim Screening auf Herzfehler}

In vielen Ländern wurde die Darstellung des 4KB als Anforderung in die Stufe-I-Screening-Untersuchung zur Fehlbildungsdiagnostik zwischen der 18. und 22. SSW integriert $[5,6]$. Dabei erzielten Länder mit etablierten Screeningprogrammen (Westeuropa, 20-48\%) höhere Detektionsraten als solche ohne feste Screeninguntersuchungen (Niederlande, Dänemark, Osteuropa; 8-11\%) [5]. Um das volle Potenzial einer solchen Untersuchung auszuschöpfen, sind standardisierte Untersuchungstechniken, die Verwendung hochauflösender Ultraschallgeräte und die entsprechende theoretische und praktische Ausbildung der Durchführenden unabdingbar.

Analysiert man verschiedene Publikationen zu Screeninguntersuchungen des fetalen Herzens, unterscheiden sich diese in vielerlei Hinsicht, was letztendlich auch die extreme Schwankungsbreite der Entdeckungsraten begründet [1, 7] ( $\bullet$ Tab. 1). Während Stufe-1-Untersucher überwiegend Low-risk-Schwangere untersuchen, ist das Untersuchungskollektiv in Stufe-III-Zentren meist ein Kollektiv mit gemischtem bis hohem Risiko; damit steigt auch die Prävalenz von Herzfehlern. Die Definition, was als „Herzfehler“ gewertet wurde, ist uneinheitlich. Während einige Studien nur schwere Herzfehler einschließen, beziehen sich andere auf im Vier-Kammer-Blick „potenziell“ entdeckbare. Unterschiede ergeben sich auch im Follow-up; während in einzelnen Studien postnatal standardisiert nachuntersucht wurde, geschah dies in anderen nur bei Auffälligkeiten oder gar nicht. Einzelne Zentren mit wenigen, hochspezialisierten Untersuchern erreichen höhere Entdeckungsraten als solche, in denen verschiedene Untersucher mit unterschiedlicher Erfahrung untersuchen.

Eine wichtige Rolle spielt der auch Untersuchungszeitpunkt. Als optimal für ein allgemeines Screening wird das Intervall 20.-22. SSW angesehen, während Untersuchungen vor der 18. SSW mit einer schlechteren Visualisierung und damit auch niedrigeren Entdeckungsraten einhergehen.

Nicht zuletzt ist die Gerätequalität (Verwendung von 3,5- vs. 5,0-MHz-Schallköpfen, Möglichkeit der farbkodierten Doppleruntersuchung), die Komplexität der Untersuchung sowie die zur Verfügung stehende Untersuchungszeit bedeutsam [9]. Die alleinige Beurteilung des Vier-Kam- 


\begin{tabular}{|c|c|c|c|c|}
\hline study & incidence (per 1000) & risk & examination & week of pregnancy \\
\hline Buskens et al. 1996 & 8 & low & $4 C V$ & $16-24$ \\
\hline Todros et al. 1997 & 4.8 & low & $4 C V$ & $18-22$ \\
\hline \multirow[t]{2}{*}{ Tegnander et al. 2006} & 3 (only critical CHD) & low & only $4 \mathrm{CV}$ & $16-22$ \\
\hline & & & $4 C V+$ outflow tractt & \\
\hline Hafner et al. 1998 & 13 & low & $4 C V+$ outflow tract & $16-22$ \\
\hline Ogge et al. 2006 & 9.1 & low & $4 C V+$ outflow tract & $>18$ \\
\hline Wong et al. 2003 & 7 & low & $4 C V+$ outflow tract & $17-24$ \\
\hline \multirow[t]{2}{*}{ Stümpflen et al. 1996} & 7 & mixed & only 4CV & $8-28$ \\
\hline & & & $4 \mathrm{CV}+$ outflow tract + colour & \\
\hline Yagel et al. 1997 & 7.6 & mixed & $4 \mathrm{CV}+$ outflow tract + colour & $13-22$ \\
\hline
\end{tabular}

ther educational programs are necessary to fully exploit the possibilities and chances of prenatal sonographic screening in general and the diagnosis of heart defects in particular. Not only the acquisition but also the interpretation of the $4 \mathrm{CV}$ can be improved by instruction and continuous practice, which would over the years lead to a continuously increasing rate of detection of heart defects by way of the $4 \mathrm{CV}$ alone $[7,8]$.

It has been shown many times that a stepwise introduction of the four-chamber view $(4 \mathrm{CV})$ into prenatal sonographic screening and then the additional evaluation of the origins and courses of the two great arteries lead to a marked increase in the detection rates [1]. Thus, the quality requirements of advanced differential diagnostic sonographic examinations (DEGUM Step II) contain, besides the $4 \mathrm{CV}$, also visualisation of the left and right ventricular outflow tracts [9].

The following text is intended to provide a comprehensive survey of the acquisition and diagnostic potential of $4 \mathrm{CV}$; the process of setting up the $4 \mathrm{CV}$, the normal structures and the detectable anomalies are illustrated. Also the possible pitfalls and limitations of the 4CV in the diagnosis of fetal heart defects are discussed. Besides structure analysis in the two-dimensional image, the use of colour Doppler sonography in evaluation of the $4 \mathrm{CV}$ or, respectively, diagnosis of the respective heart defect are presented since nowadays most sonography systems include this technique.

\section{Value of the Four-Chamber View in Screening for Heart Defects}

$\nabla$

In many countries acquisition of the $4 \mathrm{CV}$ is integrated as a requirement in stage I screening examinations for fetal anomalies between the $18^{\text {th }}$ and $22^{\text {nd }}$ weeks of pregnancy $[5,6]$. Hereby, countries with established screening programs achieved higher detection rates (West Europe, $20-48 \%$ ) than those without fixed screening examinations (Netherlands, Denmark, East Europe, $8-11 \%$ [ [5]. In order to exploit the full potential of such examinations, standardised ex- amination techniques, the use of high-resolution ultrasound equipment and the corresponding theoretical and practical training of the examiners are mandatory.

If one analyses the various publications on screening examinations of the fetal heart, they are found to differ in many respects, which ultimately also explains the extreme width of scatter of the reported detection rates $[1,7]$ ( $\odot$ Table 1 ). Whereas stage 1 examiners are mainly concerned with low-risk pregnant women, the examined collective in stage 3 centres is usually a group of mixed to high risk patients; accordingly, the prevalence of heart defects is also higher. The definition of what constitutes a "heart defect" is not uniform. While some studies have only examined severe heart defects, others refer to defects that are "potentially" detectable on the four-chamber view. There are also differences in follow-up; whereas in individual studies the follow-up examinations were standardized, this occurred in others only in cases of conspicuous findings or not at all. Individual centres with a few, highly specialized examiners achieved higher detection rates than those in which the various examiners had different levels of experience.

The time point of the examination also plays an important role. The period from $20^{\text {th }}$ to $22^{\text {nd }}$ week of pregnancy is considered to be optimal for a general screening, whereas examinations prior to the $18^{\text {th }}$ week of pregnancy are accompanied by a poorer visualisation and thus also a lower detection rate.

Last but not least, the quality of the ultrasound equipment (use of 3.5 versus $5.0 \mathrm{MHz}$ transducer, possibility for colour-coded Doppler examinations), the complexity of the examination as well as the time available for the examination are important [9]. Even under optimal conditions, evaluation of the four-chamber view alone can only detect about $40-50 \%$ of all heart defects. An increase of the sensitivity by a further $20-30 \%$ is possible by additional consideration of the outflow tracts $[8,10,11]$. Realistic estimates for Europe give a prenatal detection rate of about $20-$ $25 \%$ for fetal heart defects.

\begin{tabular}{|lc|}
\hline experience & sensitivity \\
\hline stage 1 & $5 \%$ \\
\hline stage 1 & $15 \%$ \\
\hline stage 1 & $39 \%$ \\
\hline & $57 \%$ \\
\hline stage 2 & $4 \%$ \\
\hline stage 2 & $66 \%$ \\
stages $1 / 2$ & $21 \%$ \\
stage 3 & $61 \%$ \\
stage 3 & $48 \%$ \\
\hline & $88 \%$ \\
\hline stage 3 & $81 \%$ \\
\hline
\end{tabular}

Table 1 Studies on prenatal screening of congenital heart defects, modified after [1]

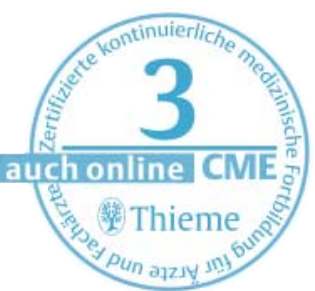


mer-Blickes kann selbst bei optimalen Bedingungen nur ca. 40-50\% aller Herzfehler entdecken. Eine Steigerung der Sensitivität um weitere $20-30 \%$ ist durch die zusätzliche Beurteilung der Ausflusstrakte möglich [8, 10, 11]. Realistische Schätzungen für Europa gehen von einer pränatalen Entdeckungsrate fetaler Herzfehler von etwa $20-25 \%$ aus.

Um das Screening weiter zu verbessern, ist die konsequente Darstellung des Vier-Kammer-Blickes in ausreichender Bildqualität durch geschulte Untersucher als fester Bestandteil einer StufeI-Untersuchung zu fordern [6].

\section{Technische Grundlagen}

$\nabla$

Verschiedene Ultraschallverfahren können bei der Untersuchung des fetalen Herzens und somit auch des $4 \mathrm{~KB}$ eingesetzt werden: die zweidimensionale (2D-)Echokardiografie (= B-Bild-Sonografie) ( $\mathbf{A b b}$.1a-c, 3a, b), die farbkodierte Doppler-Echokardiografie ( $\mathbf{A b b} . \mathbf{2 a}-\mathbf{c})$, die Spektral-Doppler-Echokardiografie ( $\bullet$ Abb. 3c), die M-Mode-Echokardiografie ( $\bullet$ Abb.4a-c) und die 3D/4D-Echokardiografie ( $\bullet$ Abb.5). In der Routine kommen vor allem die 2D-Echokardiografie und die farbkodierte Doppler-Echokardiografie zum Einsatz; die Spektral-Doppler-Echokardiografie wird zur Quantifizierung von Flussgeschwindigkeiten, zur Verifizierung von Flussauffälligkeiten im Farbdoppler-Bild und zur Differenzierung fetaler Arrhythmien eingesetzt, die M-Mode-Echokardiografie ebenfalls zur Differenzierung fetaler Arrhythmien und zur Beurteilung der Ventrikelfunktion.

Die 3D/4D-Echokardiografie hat in den letzten Jahren eine rasante Entwicklung erfahren. Vor allem nach der Einführung der STIC-Technologie (Spatio-temporal image correlation) [12], die die Probleme der Bewegungsartefakte bei fehlender Möglichkeit einer EKG-Triggerung bei der 3D-Darstellung des fetalen Herzens teilweise gelöst hat und die mit vielen anderen Ultraschallverfahren kombiniert eingesetzt werden kann (B-Flow, Farbdoppler, Power-Doppler, High-definition-flow-Doppler). Die Entwicklung neuer Matrix-Schallköpfe bietet die Möglichkeit, erstmals kleinere Herzvolumina in Echtzeit (Real time) zu untersuchen. Ob und auf welchen Gebieten der Einsatz der 3D/4D-Echokardiografie die diagnostische Qualität der fetalen Echokardiografie verbessern wird, kann derzeit noch nicht vorausgesagt werden. In jedem Fall bietet sie vielversprechende neue Visualisierungsmöglichkeiten, wie in neueren Übersichtsarbeiten dargestellt [13].

Für die fetale Echokardiografie sollten hochfrequente Ultraschallsonden (5-9 MHz) sowie die für die meisten Ultraschallsysteme erhältlichen und speziell für diesen Anwendungsbereich ent- wickelten Voreinstellungen (Presets) verwandt werden. In der B-Bild-Sonografie zeichnen sich diese Voreinstellungen durch keine oder eine niedrige Mittelung (Persistenz), eine niedrige Dynamic Range (hohes Kontrastverhältnis) sowie eine hohe Bildwiederholungsrate (Frame rate) aus: insgesamt wirkt das Bild damit härter. Um eine optimale Bildfolgefrequenz und räumliche Auflösung zu erreichen, sollte der Bildausschnitt schmal gewählt werden.

In der farbkodierten Dopplersonografie muss die vorgegebene Echokardiografie-Voreinstellung in der Regel individuell angepasst werden. Dabei sollte die Pulsrepetitionsfrequenz (PRF) so gewählt werden, dass der Einfluss ins Herz ohne Aliasing dargestellt wird $(50-100 \mathrm{~cm} / \mathrm{s})$. Zur Darstellung der langsameren venösen Flüsse (z.B. den Lungenvenen) muss die Pulsrepetitionsfrequenz entsprechend herabgesetzt werden $(10-30 \mathrm{~cm} / \mathrm{s})$. Die Nachverstärkung (Farb-Gain) sollte so hoch gewählt werden, dass nur Bereiche des Herzens kodiert werden, in denen auch Blutfluss stattfindet. Eine zu starke Steigerung des Farb-Gain führt zum „Überzeichen“ der Gefäßwände. Um einen schnellen Bildaufbau zu gewährleisten, ist die Persistenz auch in den FarbPresets niedrig eingestellt. Zusätzlich sollte man das Farbfenster möglichst klein und vor allem schmal wählen.

\section{Festlegung des Situs und Einstellen des Vier-Kammer-Blickes \\ $\nabla$}

Es ist empfehlenswert, die fetale Echokardiografie nicht am Herzen selbst zu beginnen sondern am transabdominalen Querschnitt. Hier wird der abdominelle Situs festgelegt, nachdem anhand der Poleinstellung sowie der Stellung des kindlichen Rückens die Seitenzuordnung des Ultraschallbildes erfolgt ist. Unterschieden wird der Situs solitus, der Situs inversus und der Situs ambiguus.

Beim physiologischen Situs solitus abdominalis sind Magen und deszendierende Aorta links der Wirbelsäule, während Vena cava inferior, Portalsinus und Gallenblase rechts der Wirbelsäule zur Darstellung kommen.

Die häufigste Situsanomalie in der Fetalperiode ist der Situs ambiguus (viszerokardiale Heterotaxie), ein Situs, der sich weder dem Situs solitus noch dem Situs inversus zuordnen lässt. Von einem solchen Situs spricht man z.B., wenn sowohl der Magen als auch Portalsinus und Gallenblase rechts der Wirbelsäule zur Darstellung kommen. Der Situs ambiguus ist regelmäßig (>95\%) mit komplexen kardialen Vitien vergesellschaftet [14].

Der Situs inversus mit spiegelbildlicher Anordnung der Bauchorgane (Magen und deszendierende Aorta rechts, Gallenblase, Portalsinus und 


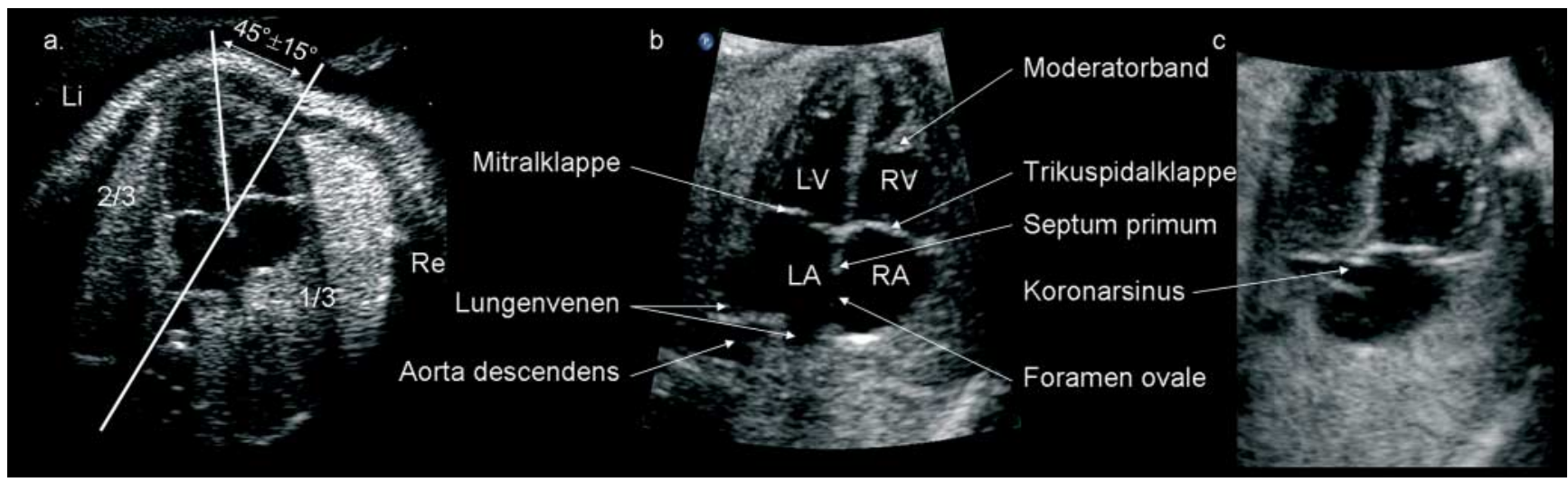

Fig. 1 a-c Two-dimensional echocardiography of the apical four-chamber view in three different settings. The survey a demonstrates the size relationships in the thorax: the axis of the heart is inclined $45^{\circ} \pm 15^{\circ}$ to the left, ${ }^{2}{ }_{3}$ of the heart lie in the left and $1 / 3$ in the right half of the thorax. The heart area accounts for $1 / 3$ of the thorax area. In the zoom view $\mathbf{b}$ the anatomic details can optimally be evaluated (the heart should occupy $30-50 \%$ of the image's area). In the caudal setting c the coronary sinus is visualised. "ras Video $1 \mathbf{a}+\mathbf{b}$, 四 Video $1 \mathrm{c}$

Abb. 1 a-c Zweidimensionale Echokardiografie des apikalen Vier-Kammer-Blickes in drei unterschiedlichen Einstellungen. Die Übersicht a demonstriert die Größenverhältnisse im Thorax: Die Herzachse ist $45^{\circ} \pm 15^{\circ}$ nach links gekippt, ${ }^{2} / 3$ des Herzens liegen in der linken und $1 / 3$ in der rechten Thoraxhälfte. Die Herzfläche nimmt $1 / 3$ der Thoraxfläche ein. In der Zoom-Ansicht b können die anatomischen Details optimal beurteilt werden (das Herz sollte $30-50 \%$ des Bildausschnittes einnehmen). In der kaudalen Einstellung c kommt der Koronarsinus zur Darstellung.

In order to further improve the screening, the consequent visualisation of the $4 \mathrm{CV}$ in sufficient image quality by well-trained examiners is required as an integral part of a stage I examination [6].

\section{Technical Principles \\ $\nabla$}

Various sonographic procedures can be employed to examine the fetal heart and thus also the four-chanber view: two-dimensional (2D) echocardiography (= B mode sonography) ( $\bullet$ Figs. 1a-c, 3a, b), colour-coded Doppler echocardiography ( Fig. $2 a-c$ ), spectral Doppler echocardiography ( $\bullet$ Fig. 3c), M mode echocardiography ( Fig. $4 a-c)$ and 3D/4D echocardiography ( $\bullet$ Fig. 5). In clinical routine, 2D echocardiography and colour-coded Doppler echocardiograpy are employed most. Spectral Doppler echocardiography is used to quantify flow velocities, to verify flow abnormalities in colour Doppler images and to differentiate fetal arrhythmias, $\mathrm{M}$ mode echocardiography is also used to differentiate fetal arrhythmias and to evaluate ventricular function.

3D/4D echocardiography has undergone rapid evolution in the last few years. Above all, introduction of STIC technology (spatio-temporal image correlation) [12] has at least in part solved the problem of movement artefacts in the absence of the possibility for ECG triggering for the $3 \mathrm{D}$ visualisation of the fetal heart and the STIC can be used in combination with many other sonographic methods (B flow, colour Doppler, power Doppler, high-definition flow Doppler). The development of new matrix transducers offers the possibility to examine for the first time smaller heart volumes in real time. If and in which fields the use of 3D/4D echocardiography will improve the diagnostic quality of fetal echocardiography cannot yet be predicted. In any case, it offers highly promising, new possibilities for visualisation as has been discussed in recent review articles [13].

High frequency ultrasound transducers (5-9 $\mathrm{MHz}$ ) and the presets specially developed for this field of applications and available for most sonographic systems should be used for fetal echocardiography. In B mode sonography these presets are characterised by low or no persistence, a low dynamic range (high contrast ratio) as well as a high frame rate: on the whole the image then appears harder. A narrow image field should be chosen in order to achieve an optimal image sequence frequency and spatial resolution.

In colour-coded Doppler sonography the echocardiographic presets must usually be adjusted individually. Here the pulse repetition frequency (PRF) should be chosen so that the inflow into the heart can be visualised without aliasing $(50-100 \mathrm{~cm} / \mathrm{sec})$. For visualisation of the slower venous flows (e.g., the pulmonary veins) the pulse repetition frequency must be reduced accordingly $(10-30 \mathrm{~cm} / \mathrm{sec})$. Subsequent amplification (colour gain) should be set so that only those regions of the heart are coded in which blood flow occurs. An excessive increase of the colour gain leads to an "overdrawing" of the vessel walls. In order to ensure a rapid image formation, the persistence in the colour preset should also be set at a low level. In addition, the color window should be as small and, above all, as narrow as possible. 

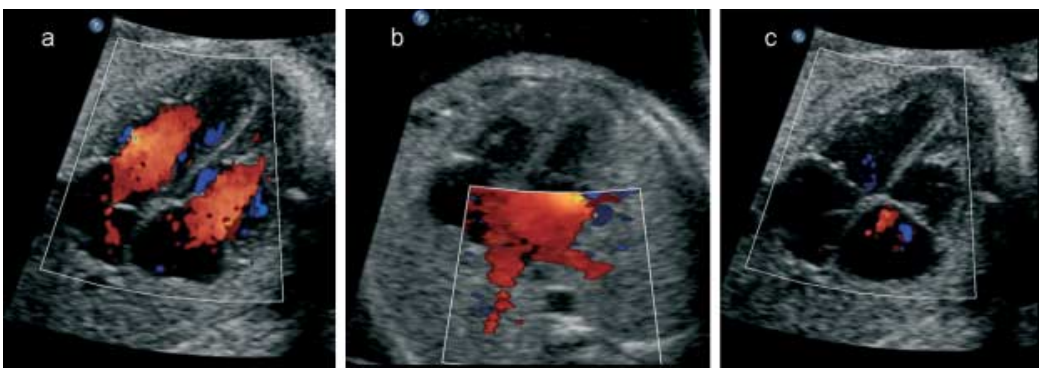

Abb. 2 a-c Farbdoppler-Echokardiografie des apikalen Vier-Kammer-Blickes. In der Diastole a lässt sich der getrennte Einfluss (rot kodiert) in beide Ventrikel darstellen. Bei niedrigen Pulsrepetitionsfrequenzen b kommen zusätzlich die in den linken Vorhof einmündenden Lungenvenen (rot kodiert) zur Darstellung. In der Systole c lässt sich kein Fluss über die Atrioventrikular-Klappen darstellen. 맘 Video $\mathbf{2 a + c}$, 四 Video $\mathbf{2 b}$

Fig. 2 a-c Colour Doppler echocardiography of the apical four-chamber view. In the diastole a the separate inflows (coded red) in the two ventricles are apparent. At low pulse repetition frequencies $\mathbf{b}$ the pulmonary veins (coded red) coursing into the left atrium are additionally visualised. In the systole $\mathbf{c}$ no flow over the atrioventricular valves can be demonstrated.

Vena cava inferior links) und Spiegelbild-Dextrokardie ist ein sehr seltener Befund, der per se zwar keinen Krankheitswert besitzt, aber ebenfalls häufig mit Herzfehlern assoziiert ist [15]. Die Festlegung des abdominellen Situs als erster Schritt bei der fetalen Echokardiografie empfiehlt sich, weil 1. sie einfach und schnell durchführbar ist, 2. ohne Seitendifferenzierung keine umfassende Beurteilung des fetalen Herzens erfolgen kann und 3. Abweichungen vom Situs solitus wichtige Hinweiszeichen auf das Vorliegen kardialer Vitien sind.

Vom transabdominellen Querschnitt (möglichst von apikal) schwenkt man den Schallkopf nach kranial auf das kindliche Köpfchen zu. So wird die etwas schräg im Thorax befindliche Ebene des 4KB aufgefunden, die von kaudal-apikal nach kranial-dorsal ansteigt ( $\bullet$ Abb. 1). Bei dorsoanteriorer Lage muss von dorsal eingeschallt werden und das Einstellen des $4 \mathrm{~KB}$ ist entsprechend schwieriger.

Nach der Beurteilung der Thoraxanatomie in der Übersicht sollte das Herz zur Bildoptimierung herausvergrößert werden (im 4KB sollte das Herz mindestens 40-50\% des Bildausschnittes einnehmen) ( $\bullet$ Abb.1b). Mittels Cine-loopFunktion kann dann die Anatomie in den einzelnen Herzzyklen am eingefrorenen Bild beurteilt werden.

\section{Physiologische Befunde im Vier-Kammer-Blick $\nabla$}

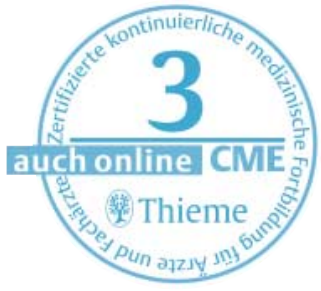

Im 4KB ( Abb. 1a) zeigt die Herzspitze nach links und die Herzachse ist $45^{\circ} \pm 15^{\circ}$ nach links gekippt. Zwei Drittel des Herzens liegen in der linken Thoraxhälfte und das Herz nimmt rund ein Drittel der Thoraxfläche ein. Das Herz schlägt im Sinusrhythmus mit einer Frequenz von 110-160 Schlägen/Minute und einer 1:1-Überleitung zwischen Vorhöfen und Ventri- keln. Der rechte Ventrikel liegt thoraxwandnah, ist stärker trabekuliert und trägt im apikalen Teil das Moderatorband ( $\bullet$ Abb. 1b). Der linke Ventrikel ist spitzenbildend und wirkt aufgrund seiner schwächeren Trabekulierung schlanker. Die Trikuspidalklappe inseriert etwas weiter apikal am Ventrikelseptum, während die Mitralklappe etwas weiter dorsal am Herzkreuz inseriert. Dieser Versatz des Klappenansatzes beträgt beim Fetus 1-2 mm [16]. Die einzige physiologische Kontinuitätsunterbrechung der Herzsepten findet sich im Bereich des Foramen ovale. Die Klappe des Foramen ovale inseriert am Septum primum und schlägt nach links. In den linken Vorhof münden von dorsal die Lungenvenen. Hinter dem Herzen findet sich nur ein Gefäß links von der Wirbelsäule und in unmittelbarer Nähe des linken Vorhofes quer angeschnitten: die Aorta descendens. Schallt man streng auf der Basis des 4KB (d.h. kaudal), kommt in unmittelbarer Nähe und parallel zur Mitralklappe im linken Vorhof der Koronarsinus zur Darstellung ( $\bullet$ Abb.1c). Dieser bringt das sauerstoffarme koronarvenöse Blut zurück zum Herzen, „untertunnelt“ den linken Vorhof und mündet in den rechten Vorhof.

In der Farbkodierung lassen sich in der Diastole zwei getrennte Einflüsse in beide Ventrikel darstellen, die sich gleichmäßig füllen und durch das Ventrikelseptum getrennt sind ( $\bullet$ Abb.2a). Auf der Vorhofebene kommt bei seitlicher Einstellung der Rechts-links-Shunt über das Foramen ovale zur Darstellung. Bei optimaler Winkeleinstellung und Verwendung entsprechend niedriger Pulsrepetitionsfrequenzen lassen sich die vier von dorsal in den linken Vorhof einmündenden Lungenvenen darstellen ( $\bullet$ Abb. 2b). In der Systole sollte kein Rückfluss über die AVKlappen in die Vorhöfe zur Darstellung kommen ( $\bullet$ Abb. 2c). Eine milde frühsystolische Trikuspidalinsuffizienz kommt allerdings bei bis zu 7\% der Feten im zweiten Trimenon vor. Dieser Befund ist meist transient und überwiegend als physiologisch zu werten [17]. Eine Mitralregurgitation ist dagegen sehr selten physiologisch.

- Tab. 2 fasst die wichtigsten physiologischen Befunde im 4KB in einer Checkliste zusammen.

\section{Auffälligkeiten im Vier-Kammer-Blick \\ $\nabla$}

Auffälligkeiten im 4KB können den Herzrhythmus, die Herzgröße, die Lage des Herzens, die Herzachse, die Herzsepten, die Atrioventrikularklappen, die Ventrikelmorphologie und die Gefäße hinter dem Herzen betreffen.

\section{Herzrhythmus}

Arrhythmien werden, sofern sie nicht im Rahmen der Dopplersonografie auffallen, vornehmlich im 4KB diagnostiziert. Die Differenzialdiagnostik der Rhythmusstörungen basiert grundsätzlich 


\section{Definition of the Situs and visualisation of the Four-Chamber View \\ $\nabla$}

It is recommended not to begin fetal echocardiography at the heart itself but rather at a transabdominal cross-section. Hereby the abdominal situs is defined after the lateral orientation of the sonographic image has been fixed on the basis of the pole settings as well as the position of the child's back. One distinguishes between situs solitus, situs inversus and situs ambiguus.

In the physiological abdominal situs solitus the stomach and descending aorta are visualised to the left of the spinal column whereas the vena cava, portal sinus and gallbladder appear to the right of the spinal column.

The most frequent situs anomaly in the fetal period is the situs ambiguus (viscerocardiac heterotaxia), a situs that can be assigned neither as a situs solitus nor as a situs inversus. One speaks of such a situs when, e.g., the stomach, the portal sinus and the gallbladder are visualised to the right of the spinal column. The situs ambiguus is regularly (>95\%) accompanied by complex cardiac defects [14].

The situs inversus with a mirror-image arrangement of the abdominal organs (stomach and descending aorta on the right, gallbladder, portal sinus and vena cava on the left) and dextrocardia is a very rare finding which, although it per se has no clinical relevance, is also often associated with heart defects [15].

The definition of the abdominal situs as first step in fetal echocardiography is worthwhile because 1. it can be performed very simply and quickly, 2. without the differentiation of sides a correct evaluation of the fetal heart is not possible, and 3. deviations from the situs solitus are important signs for the presence of cardiac defects.

From the transabdominal cross-section (preferably apical), the transducer is moved cranially towards the child's head. In this way the plane of the $4 \mathrm{CV}$ can be found; it is somewhat inclined in the thorax and rises from caudal-apical to cranial-dorsal ( $\bullet$ Fig. 1 ). In the case of a dorsoanterior position sonography must be performed from dorsal and acquisition of the 4CV is correspondingly more difficult.

After evaluation of the anatomy of the thorax in a survey image, the view of the heart should be magnified for image optimisation (in the $4 \mathrm{CV}$ the heart should occupy at least $40-50 \%$ of the image section) ( $\bullet$ Fig. 1b). By means of a cineloop function, the anatomy of individual heart cycles can be evaluated in frozen images.

\section{Physiological Findings in the Four- Chamber View \\ $\nabla$}

In the 4CV ( $\bullet$ Fig. 1a) the apex of the heart points to the left and the axis of the heart is inclined
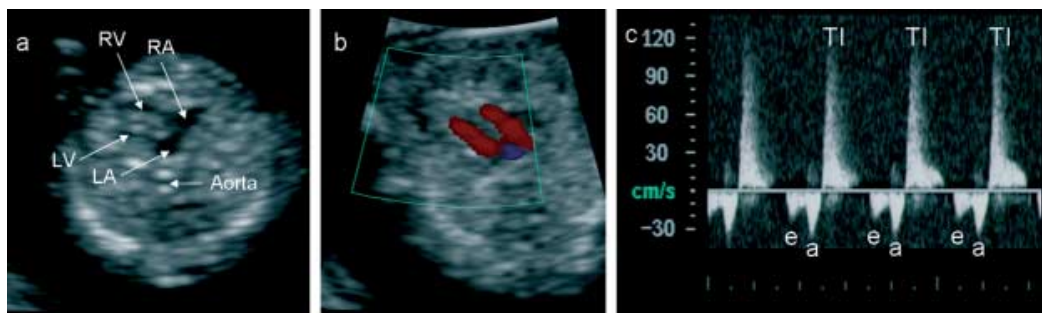

Fig. 3 a-c Transvaginal sonography of the four-chamber view in the $11+0$ week of pregnancy. In the $B$ mode image a both ventricles, both atria, the intact ventricular septum and the descending aorta can be seen (RV, right ventricle; RA, right atrium; LV, left ventricle; $L A$, left atrium). Colour Doppler sonography $\mathbf{b}$ demonstrates in the diastole the separate inflows (coded red) into the two ventricles. Spectral Doppler of the tricuspid valve c shows in negative Doppler spectrum the physiological filling pattern of the right ventricle with e-waves (early diastole = passive filling phase) and a-waves (atrial contraction = active filling phase). In the positive Doppler spectrum the "jet" of a tricuspid regurgitation with a maximum velocity of $>120 \mathrm{~cm} / \mathrm{sec}$ is represented (e, e-wave; a, a-wave; TI, tricuspid regurgitation). 回 Video 3a+b, "며 Video 3c

Abb. 3 a-c Transvaginale Sonografie des Vier-Kammer-Blickes in der 11+0. SSW. Im B-Bild a kommen die beide Ventrikel, beide Vorhöfe, das intakte Ventrikelseptum und die deszendierende Aorta zur Darstellung (RV, rechter Ventrikel; RA, rechter Vorhof; LV, linker Ventrikel; LA, linker Vorhof). Die Farbdoppler-Sonografie $\mathbf{b}$ demonstriert in der Diastole den getrennten Einfluss (rot kodiert) in beide Ventrikel. Der Spektraldoppler der Trikuspidalklappe c zeigt im negativen Dopplerspektrum das physiologische Füllungsmuster des rechten Ventrikels mit e-Welle („early diastole" = passive Füllungsphase) und a-Welle (atriale Kontraktion = aktive Füllungsphase). Im positiven Dopplerspektrum ist der „Jet“ einer Trikuspidalregurgitation mit einer Maximalgeschwindigkeit von $>120 \mathrm{~cm} / \mathrm{s}$ dargestellt (e, e-Welle; a, a-Welle; TI, Trikuspidalregurgitation).

$45^{\circ} \pm 15^{\circ}$ to the left. Two-thirds of the heart is in the left half of the thorax and the heart occupies about a third of the area of the thorax. The heart beats in a sinus rhythmus with a frequency of $110-160$ beats/minute and a 1:1 conduction between atria and ventricles. The right ventricle lies near the thorax wall, is more strongly trabeculated, and carries the moderator band in the apical part ( Fig. 1b). The left ventricle forms the apex and appears slimmer because of its weaker trabeculation. The tricuspid valve inserts somewhat more apical on the ventricular septum, whereas the mitral valve inserts somewhat further dorsal. This shift of the valve insertion amounts to 1 $2 \mathrm{~mm}$ in the fetus [16]. The only physiological interruption of the heart septa is found in the region of the foramen ovale. The valve of the foramen ovale inserts in the septum primum and courses to the left. The pulmonary veins run from dorsal into the left atrium. Behind the heart there is only one vessel to the left of the spinal column and obliquely imaged in close vicinity of the left atrium: the descending aorta. On strict insonation on the base of the $4 \mathrm{CV}$ (i. e., from caudal), the coronary sinus is visualised in the left atrium in close proximity and parallel to mitral valve ( Fig. 1c). This brings oxygen-depleted coronary venous blood back into the heart, tunnels under the left atrium and courses into the right atrium.

On colour coding, symmetrically separated inflows of the two ventricles, which fill uniformly and are separated by the ventricular septum, can be visualised in the diastole ( $\bullet$ Fig. 2a). On insonation from the side, the right-left shunt at the level of the atrium can be visualised above the foramen ovale. With an optimal angle and low 

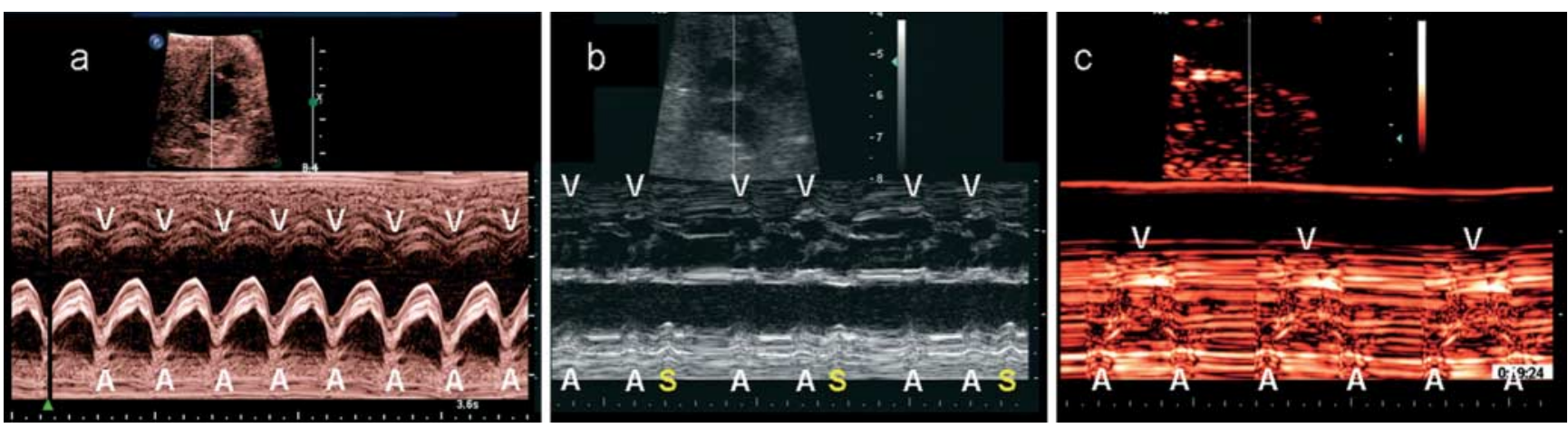

Abb. 4 a-c M-Mode-Sonografie im Vier-Kammer-Blick. a zeigt den physiologischen Sinusrhythmus mit 1:1-Überleitung. Jede Vorhofkontraktion (A) ist von einer Ventrikelkontraktion gefolgt. b zeigt eine supraventrikuläre 2:1-Extrasytolie. Jede zweite Vorhofkontraktion (A) ist von einer supraventrikulären Extrasystole ohne AV-Überleitung gefolgt, daher fällt jede dritte Ventrikelaktion aus. c zeigt einen AV-Block II ${ }^{\circ}$. Der Vorhofrhythmus ist regelmäßig und normofrequent, aber nur jede zweite Vor-

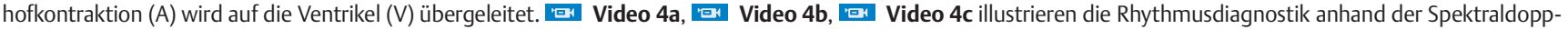
leruntersuchung der Nierengefäße. Die Dopplerspektren von Arterie und Vene werden simultan abgeleitet: a, Sinusrhythmus; b, Bigeminus; c, AV-Block III Fig. 4 a-c M mode sonography in four-chamber view. Image a shows the physiological sinus rhythm with 1:1 transmission. Each atrial contraction (A) is followed by a ventricular contraction (V). Image b shows supraventricular 2:1 extrasystoles. Every second atrial contraction (A) is followed by a supraventricular extrasystole (S) without AV transmission, thus every third ventricular action is absent. Image c shows a $2^{\text {nd }}$ degree AV block. The atrial rhythm is regular and of normal frequency but only every second atrial contraction $(A)$ is transmitted to the ventricle $(V)$.

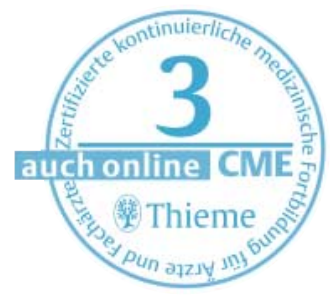

auf der Bestimmung der Herzfrequenz, des Herzrhythmus und der simultanen Darstellung von Vorhof- und Ventrikelkontraktionen bzw. dadurch ausgelöster Blutflussphänomene mit zeitlich hochauflösenden Verfahren (M-Mode und Spektral-Doppler). Dies erlaubt Rückschlüsse auf den elektrischen Erregungsablauf sowie die Analyse der atrioventrikulären (AV) Überleitung. Im $4 \mathrm{~KB}$ werden mittels M-Mode-Sonografie die Vorhof- und Kammerkontraktionen simultan (im M-Mode-Cursor) dargestellt ( $\mathbf{A b b}$.4a) oder mittels PW-Doppler simultan (im gleichen sample volume) der Blutfluss über die Mitralklappe und den linksventrikulären Ausflusstrakt. Auch die AV-Überleitungszeit lässt sich so messen.

Die mit Abstand häufigste fetale Arrhythmie ist die supraventrikuläre Extrasystolie (SVES). Diese Vorhof-Extrasystolen können oder können nicht auf das Ventrikelmyokard übergeleitet werden, sodass es zu einer vorzeitig einfallenden Ventrikelsystole kommt oder diese auch fehlen kann; für die SVES charakteristisch ist eine nicht-kompensatorische postextrasystolische Pause. Abhängig von der Häufigkeit der SVES und ihrer AV-Überleitung führt dies zu unregelmäßigen ventrikulären Kontraktionen, die sich auch bei der Doppler-Sonografie in den peripheren Arterien nachweisen lassen. Seltener treten die SVES in einem fixen Verhältnis (z.B. im 1:1-Rhythmus [bigeminal] oder 2:1-Rhythmus) zu den physiologischen Vorhofkontraktionen auf und führen bei fehlender AV-Überleitung zu einem langsamen, aber regelmäßigen Ventrikelrhythmus ( Abb. 4b).

Im Gegensatz zu den SVES findet sich z. B. bei einem AV-Block, der ebenfalls mit einer langsamen Ventrikelfrequenz assoziiert sein kann (40-80 Schläge/Minute), ein regelmäßiger normofrequenter Vorhofrhythmus, da die elektrische Erregung erst unterhalb des Vorhofs im AV-Knoten blockiert wird ( $\mathrm{Abb} .4 \mathrm{c}$ ).
Die SVES werden vom Fetus gut toleriert und sind prognostisch immer günstig einzuschätzen, selbst wenn sie, wie bei bigeminalen Extrasystolen ohne AV-Überleitung, zu einem langsamen Ventrikelrhythmus von 60-80 Schlägen/ Minute führen. Hingegen kann ein kompletter AV-Block, bei dem die Ventrikelfrequenzen zwischen 40 und 60 Schläge/Minute liegen, bei einem Teil der Feten bereits in utero zu Herzinsuffizienz, Hydrops und Tod führen [18].

Auch die wichtige Differenzierung der Tachyarrhythmien in Vorhofflattern, supraventrikuläre Reentry-Tachykardie mit 1:1-AV-Überleitung und Kammertachykardie gelingt mit M-Mode und/oder Doppler-Echokardiografie [19].

Tab. 2 Checkliste für den Vier-Kammer-Blick

B-Bild-Sonografie
- Sinusrhythmus
- Herzachse $45^{\circ}$ nach links gekippt
- Herz nimmt $1 / 3$ der Thoraxfläche ein
- ${ }^{2 / 3}$ des Herzens liegen in der linken, $1 / 3$ in der
rechten Thoraxhälfte
- beide Ventrikel gleich groß
- rechter Ventrikel thoraxwandnah mit Moderatorband
- linker Ventrikel spitzenbildend
- kompetentes Ventrikelseptum
- Herzkreuz kompetent
- Trikuspidalklappe inseriert 1 - 2 mm weiter apikal
am Ventrikelseptum als Mitralklappe
- symmetrische Kontraktilität beider Ventrikel
- Öffnungsbewegung beider Atrioventrikularklappen
- Foramen ovale schlägt in den linken Vorhof
- hinter dem Herz wird nun ein Gefäß links der Wir-
belsäule quer angeschnitten
Farb-Doppler-Sonographie
- symmetrischer getrennter Einfluss in beide Kam-
mern in der Diastole
- kein Fluss über das Ventrikelseptum
- Rechts-links-Shunt auf Vorhofebene (Foramen ovale)
- keine Regurgitation über die AV-Klappen in der Sys-
tole


pulse repetition frequency, the four pulmonary veins entering into the left atrium from dorsal can be seen ( $\mathbf{F i g} . \mathbf{2 b}$ ). In the systole no regurgitation over the AV valves into the atria should be visible ( $\bullet$ Fig. 2c). A mild early systolic tricuspid insufficiency, however, occurs in up to $7 \%$ of fetuses in the second trimester. This finding is usually transient and can generally be considered as physiological [17]. In contrast, mitral regurgitation is very rarely physiological.

- Table 2 summarises the most important physiological findings in the $4 \mathrm{CV}$ in the form of a checklist.

\section{Conspicuous Findings in Four-Chamber View \\ $\nabla$}

Conspicuous findings in the $4 \mathrm{CV}$ can affect the heart rate, the size of the heart, the position of the heart, the axis of the heart, the septa of the heart, the atrioventricular valves, the morphology of the ventricles and the vessels behind the heart.

\section{Heart rate}

When not observed already in Doppler sonography, arrhythmias are principally diagnosed in $4 \mathrm{CV}$. The differential diagnosis of arrhythmias is generally based on determination of the heart rate and the simultaneous visualisation of atrial and ventricular contractions or, respectively, the blood flow phenomena resulting therefrom by temporal high-resolution procedures ( $\mathrm{M}$ mode and spectral Doppler). This allows conclusion to

Table 2 Checklist for the four-chamber view

\begin{tabular}{|c|}
\hline B Mode sonography \\
\hline - sinus rhythm \\
\hline - axis of heart inclined $45^{\circ}$ to the left \\
\hline - heart occupies $1 / 3$ of the thorax area \\
\hline $\begin{array}{l}-2 / 3 \text { of the heart lie in the left, } 1 / 3 \text { in the right half } \\
\text { of the thorax }\end{array}$ \\
\hline - both ventricles of equal size \\
\hline - right ventricle near thorax wall with moderator band \\
\hline - left ventricle forms apex \\
\hline - competent ventricular septum \\
\hline - competent chordae tendineae \\
\hline $\begin{array}{l}\text { - tricuspid valve inserts } 1-2 \mathrm{~mm} \text { further apical at the } \\
\text { ventricular septum than the mitral valve }\end{array}$ \\
\hline - symmetrical contractility of both ventricles \\
\hline - opening movements of both atrioventricular valves \\
\hline - oval foramen beats in the left atrium \\
\hline $\begin{array}{l}\text { - only one vessel descends behind the heart on the left } \\
\text { side of the spinal column }\end{array}$ \\
\hline Colour Doppler \\
\hline $\begin{array}{l}\text { - symmetrically separated inflow in both ventricles in } \\
\text { the diastole }\end{array}$ \\
\hline - no flow over the ventricular septum \\
\hline $\begin{array}{l}\text { - right-left shunt at the level of the atrium (oval fora- } \\
\text { men) }\end{array}$ \\
\hline - no regurgitation over the $\mathrm{AV}$ valves in the systole \\
\hline - pulmonary veins run into the left atrium \\
\hline
\end{tabular}

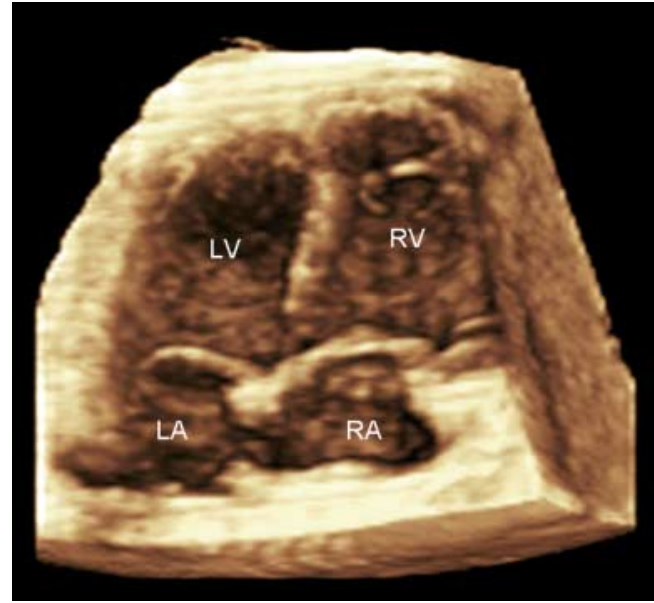

Fig. 5 Three-dimensional representation of the fourchamber view (rendering in surface mode). Abb. 5 Dreidimensionale Darstellung des Vier-KammerBlickes (Rendering im Oberflächenmodus).

be drawn about the electrical excitation processes as well as an analysis of atrioventricular (AV) conduction. In the $4 \mathrm{CV}$ the atrial and ventricular contractions (in M mode cursor) can be visualised simultaneously by mean of the M mode sonography ( $\odot$ Fig. 4a) or the blood flow over the mitral valve and the left ventricular outflow tract (in the same sample volume) can be seen simultaneously by means of PW Doppler. AV conduction time can also be estimated in a similar manner.

The by far most common fetal arrhythmia is the supraventricular extrasystoles (SVES). These atrial ectopic beats may or may not be transmitted to the ventricular myocardium, so that a prematurely occurring ventricular systole may be present or absent; characteristic for SVES is a non-compensatory, post-extrasystolic pause. Depending on the incidence of SVES and their $\mathrm{AV}$ conduction, this leads to irregular ventricular contractions that can also be detected in the peripheral arteries by Doppler sonography. Less commonly SVES occur in a fixed relation (e.g., in a $1: 1$ rhythm [bigeminal] or a $2: 1$ rhythm) to the physiological atrial contractions and lead, in the absence of $\mathrm{AV}$ conduction, to a slower but regular ventricular rhythm ( $\bullet$ Fig. 4b).

In contrast to SVES, in the case of an AV block, for example, which can also be associated with a slow ventricular frequency $(40-80$ beats/minute), a regular, normal frequency atrial rhythm is seen since the electrical excitation is first blocked in $A V$ nodes below the atrium ( $\bullet$ Fig. 4c).

SVES are well tolerated by fetuses and always have a favourable prognosis even when they, like bigeminal extrasystoles without AV conduction, lead to a slow ventricular rhythm of $60-80$ beats/minute. On the other hand, a complete AV block in which the ventricular frequency lies between 40 and 60 beats/minute, can even in utero lead to cardiac insufficiency, hydrops and death [18]. 

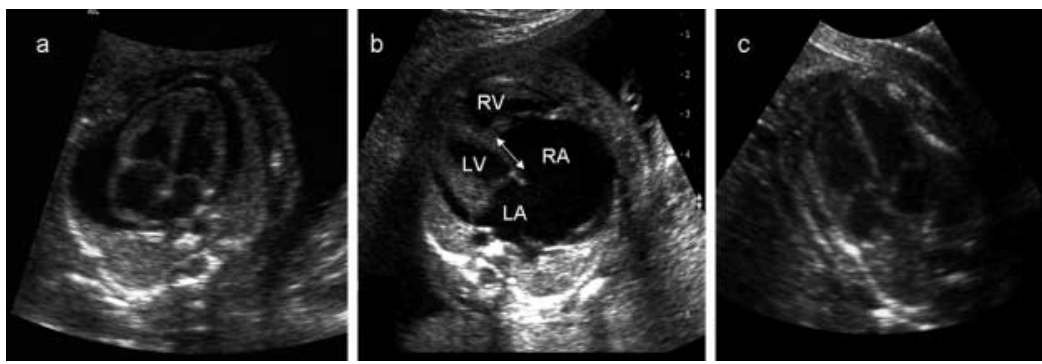

Abb. 6 a-c Vier-Kammer-Blick mit auffälliger kardiothorakaler Ratio (Herzfläche/Thoraxfläche $>1 / 3$ ). a Kardiomegalie mit ausgeprägtem Perikarderguss im Rahmen einer fetalen Anämie. b Kardiomegalie im Rahmen einer Ebstein'sch en Anomalie. Der rechte Ventrikel (RV) ist im Vergleich zum linken Ventrikel (LV) klein, der rechte Vorhof (RA) ist massiv dilatiert. Die Trikuspidalklappe setzt mehr als $1 \mathrm{~cm}$ weiter apikal am Ventrikelseptum an als die Mitralklappe (Pfeil). c Thoraxdysplasie im Rahmen einer schweren und länger bestehenden Anhydramnie.

\section{回 Video 6a, 四 Video 6b, 回 Video 6c}

Fig. 6 a-c Four-chamber view with increased cardiothoracic ratio (heart area/thorax area $>1 / 3$ ). a Cardiomegaly with pronounced pericardial effusion in the course of fetal anemia.

b Cardiomegaly in association with Ebstein's anomaly. The right ventricle (RV) is small in comparison with the left ventricle (LV), the right atrium (RA) is massively dilated. The tricuspid valve inserts more than $1 \mathrm{~cm}$ further apical than the mitral valve (arrow). $\mathbf{c}$ Thoracic dysplasia in the course of a severe and long-standing anhydremia.

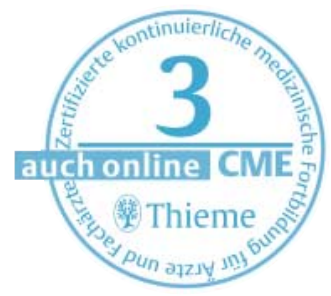

\section{Herzgröße}

Kardiomegalien mit einer kardiothorakalen Flächen-Ratio $($ CTCR $)>1 / 3$ kommen vor allem sekundär bei high cardiac output failure im Rahmen fetaler Anämien ( $\bullet$ Abb.6a), arteriovenöser Malformationen (Aneurysma der V. Galeni, Hämangiomata diverser Lokalisation, Steißbeinteratom, Chrangiom) und feto-fetalem Transfusions-Syndrom vor. Sie können aber auch primär kardialen Ursprungs sein z. B. bei Herzmuskelerkrankungen unterschiedlicher Ätiologie, kardialen Vitien, wie der Ebstein'schen Anomalie ( $\triangle$ Abb. 6b) oder persistierender Tachyarrhythmien und AV-Blockierungen. Thoraxdysplasien bzw. Lungenhypoplasien, die in Folge von Skelettdysplasien oder lang bestehender Anhydramnien auftreten, sind mit einer erhöhten kardiothorakalen Ratio verbunden, allerdings ohne dass eine eigentliche Kardiomegalie vorliegt ( $\bullet$ Abb. $6 c$ ).

Kompressionen des Herzens haben ihren Ursprung meist in intrathorakalen raumfordernZwerchfellhernien ( $\boldsymbol{A} \mathbf{A b b} . \mathbf{7 b}$ ) oder den seltenen Larynxatresien. Letztere führen sekundär $\mathrm{zu}$ einer massiven Hypertrophie der Lungen und einer Kompression des Herzens ( $\boldsymbol{Q}$ Abb. 7c).

\section{Herzlage}

Treten die thorakalen Raumforderungen unilateral auf, wird das Herz zur Gegenseite verdrängt und es resultiert eine Dextroposition bzw. Sinistroposition des Herzens, z. B. bei einer Zwerchfellhernie ( $\bullet \mathbf{A b b} . \mathbf{8 a})$, einer zystisch adenomatoiden Lungenmalformation (CCAML) ( $\bullet$ Abb. 8b) oder eines Lungensequesters ( $\boldsymbol{A}$ Abb. 8c). Bei diesen Erkrankungen des Fetus ist die Mediastinalverlagerung meist das führende sonografische Hinweiszeichen. den Prozessen, z.B. Hydrothoraces ( $\odot$ Abb. 7a),

\section{Herzachse}

Dextrokardien und Mesokardien, bei denen nicht das gesamte Herz verdrängt ist, sondern eine Fehlrotation der Herzachse vorliegt, treten häufig im Rahmen von Heterotaxie-Syndromen auf und sind dann fast immer mit komplexen kardialen Vitien und Situsanomalien vergesellschaftet. Aber auch die Dextrokardie bei Situs solitus ist häufig mit Herzfehlern assoziiert (66-95\%) [15]. Daher sind Abweichungen von der physiologischen Herzachse wichtige Hinweiszeichen auf das Vorliegen von Herzfehlern.

Einige kardiale Vitien können bereits im 4KB eindeutig differenziert werden, bei anderen fallen lediglich sekundäre Veränderungen der Vorhöfe und/oder Kammern auf, während der eigentliche Herzfehler erst durch Beurteilung des Ausflusstraktes diagnostizierbar ist (O Tab. 3).

Vitien, die primär im 4KB diagnostiziert werden, betreffen vor allem die Herzsepten und die Atrioventrikularklappen, aber auch die Ventrikelanordnung selbst.

\section{Herzsepten}

Ventrikelseptum-Defekte machen 30\% der angeborenen Herzfehler aus und sind bei Einbeziehung der atrioventrikulären Septum-Defekte auch intrauterin die am häufigsten diagnosti-

Tab.3 Anomalien des Herzens die mit einem auffälligen Vier-Kammer-Blick assoziiert sind

\begin{tabular}{l} 
Arrhythmien \\
Perikarderguss \\
Lageanomalien \\
- Dextrokardie \\
- Mesokardie \\
- Dextroposition \\
- Sinistroposition \\
Größenveränderungen des Herzens \\
- Kardiomegalie \\
- Kompressionen des Herzens \\
\hline Hypoplasien oder Hypertrophien der Ventrikel \\
- Aortenisthmusstenosen ${ }^{1}$ \\
- Stenosen/Atresien der Semilunarklappen ${ }^{1}$ \\
\hline Defekte des Ventrikelseptums \\
- Singulärer Ventrikel \\
- Große Ventrikelseptum-Defekte \\
- Atrioventrikulärer Septum-Defekt \\
- Double inlet ventricle \\
\hline Anomalien der AV-Klappen \\
\hline - Mitralatresie \\
- Trikuspidalatresie \\
- Ebstein Anomalie/Trikuspidaldysplasie \\
\hline Lungenvenenfehlmündungen \\
\hline Herztumore \\
- Rhabdomyome \\
- Teratome \\
- Fibrome \\
\hline Ectopia cordis \\
Nur die sekundären Veränderungen der Ventrikel fallen \\
bei hochgradigen Stenosen im 4KB auf. \\
\hline
\end{tabular}


In addition, the important differentiation of tachyarrhythmias into atrial flutter, supraventricular reentry tachycardia with 1:1 AV transmission and ventricular tachycardia is possible with M mode and/or Doppler echocardiography [19].

\section{Cardiac size}

Cardiomegaly with a cardiothoracic area ratio $($ CTAR $)>1 / 3$ occurs above all secondary to high cardiac output failure in fetal anemias ( $\bullet$ Fig. 6a), arteriovenous malformations (aneurysms of Galen's vein, hemangiomas of diverse localisations, coccygeal teratoma, chorangioma) and feto-fetal transfusion syndrome. They can, however, also be of primary cardiac origin, e.g., in cardiomyopathies of various aetiologies, cardiac defects such as Ebstein's anomaly ( $\bullet$ Fig. $\mathbf{6 b}$ ) or persisting tachyarrhythmias and AV blockades. Thoracic dysplasias or, respectively, pulmonary hypoplasias that occur as a result of skeletal dysplasias or long-standing anhydremias are associated with an elevated cardiothoracic ratio, however, without the occurrence of an actual cardiomegaly ( $\bullet$ Fig. $6 c$ ).

Compressions of the heart are usually due to intrathoracic space-occupying processes, e.g., hydrothorax $(\bullet$ Fig. 7a), diaphragmatic hernias $(\bullet$ Fig. 7b) or the rare laryngeal atresia. The latter leads secondarily to a massive hypertro-

Table 3 Anomalies of the heart that are associated with a conspicuous four-chanber view

\begin{tabular}{l} 
arrhythmias \\
pericardial effusion \\
positional anomalies \\
- dextrocardia \\
- mesocardia \\
- dextroposition \\
- sinistroposition \\
changes in size of the heart \\
- cardiomegaly \\
- compression of the heart \\
hypoplasias or hypertrophies of the ventricle \\
- aorten isthmus stenoses ${ }^{1}$ \\
- stenoses/atresias of the semilunar cusp ${ }^{1}$ \\
defects of the ventricular septum \\
- singular ventricle \\
- large ventricular spetum defect \\
- atrioventricular septum defect \\
- double inlet ventricule \\
anomalies of the AV valves \\
- mitral atresia \\
- tricuspid atresia \\
- Ebstein's anomaly/tricuspid dysplasia \\
incorrect course of pulmonary veins \\
cardiac tumours \\
- rhabdomyoma \\
- teratoma \\
- fibroma \\
ectopia cordis \\
\hline radenoses are conspicuous in the 4 CV. \\
\hline
\end{tabular}
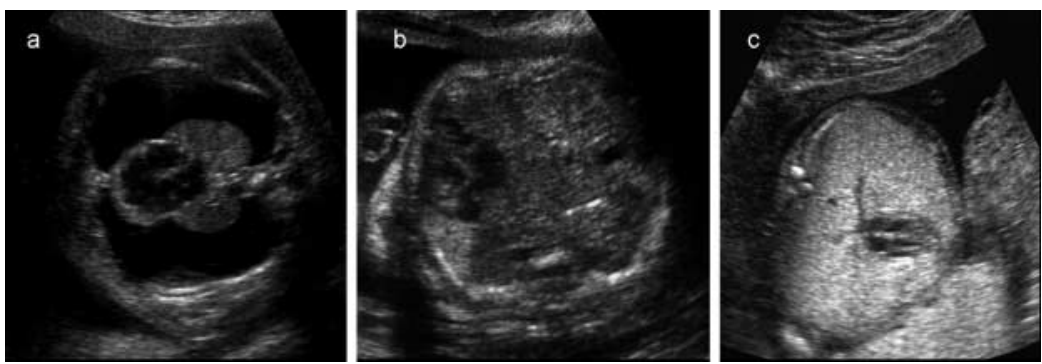

Fig. 7 a-c Four-chamber view with reduced cardiothoracic ratio and bilateral hydrothoraxes a, a bilateral diaphragmatic hernia $\mathbf{b}$ and a laryngeal atresia with consecutive, massively enlarged lungs c. "먼 Video 7a, 먼 Video 7b, 밈 Video 7c

Abb. 7 a-c Vier-Kammer-Blick mit verringerter kardiothorakaler Ratio bei bilateralen Hydrothoraces a, einer bilateralen Zwerchfellhernie b und einer Larynxatresie mit konsekutiv massiv vergrößerten Lungen c.

phy of the lungs and compression of the heart (॰ Fig. 7c).

\section{Position of the heart}

If thoracic space-occuyping processes occur unilaterally, the heart is pushed to the opposite side and a dextro- or, respectively, sinistroposition of the heart occurs, e.g., in cases of diaphragmatic hernia ( $\bullet$ Fig. 8a), congenital cystic adenomatoid malformation of the lung (CCAML) ( $\bullet$ Fig. $8 \mathbf{b}$ ) or a pulmonary sequestration ( $\bullet$ Fig. 8 c). In fetuses the cardinal sonographic sign of these diseases is usually a mediastinal shifting.

\section{Axis of the heart}

Dextrocardias and mesocardias, in which the entire heart is not shifted but where there is rather an abnormal rotation of the axis of the heart, often occur in heterotaxy syndromes and are then almost always accompanied by complex cardiac defects and situs anomalies. But dextrocardia in situs solitus is also often associated with heart defects (66-95\%) [15]. Thus, deviations from the physiological axis of the heart are an important sign for the presence of cardiac defects.

Some cardiac defects can be unambiguously differentiated already in the $4 \mathrm{CV}$, while in others merely secondary changes in the atria and/or ventricles are apparent whereas the actual cardiac defect can be diagnosed only after evaluation of the outflow tracts ( Table 3 ).

Defects that are primarily diagnosed in the $4 \mathrm{CV}$ affect above all the cardiac septa and the atrioventricular valves as well as the arrangement of the ventricles themselves.

\section{Septa of the heart}

Ventricular septal defects account for $30 \%$ of all the hereditary cardiac defects and, with the atrioventricular septal defects, are the most frequent abnormalities diagnosed in utero [2022]. Ventricuclar septal defects are differentiated according to localisation into inlet (below the AV valves), muscular (in the trabecular septum) 

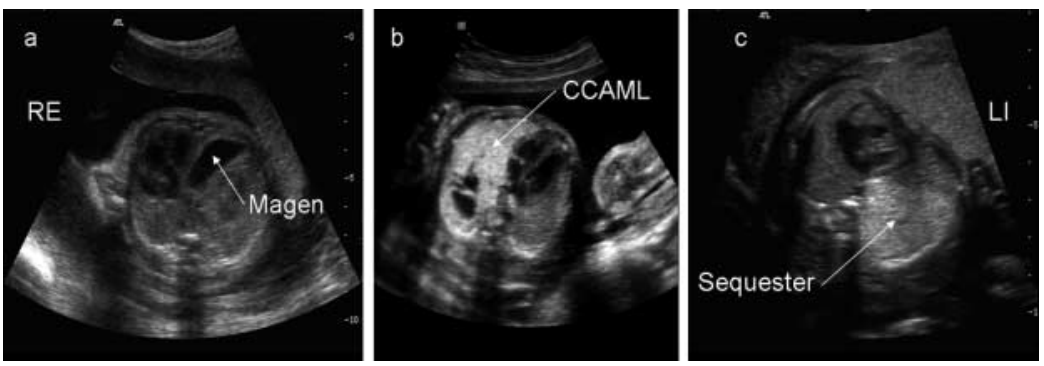

Abb. 8 a-c Lageanomalien des Herzens im Vier-Kammer-Blick. a Dextroposition im Rahmen einer linksseitigen Zwerchfellhernie mit in den Thorax hernierten Magen. b Sinistroposition im Rahmen einer rechtsseitigen adenomatoiden Lungenmalformation (CCAML). c Dextroposition im Rahmen eines linksseitigen Sequesters. 멈 Video 8a, 멈 Video 8b, 멈 Video 8c Fig. 8 a-c Positional anomaly of the heart in four-chamber view. a Dextroposition in the case of a left-sided diaphragmatic hernia with the stomach herniated into the thorax. b Sinistroposition in the case of a right-sided cystic adenomatoid malformation of the lung (CCAML). c Dextroposition in the case of a left-sided sequestration.
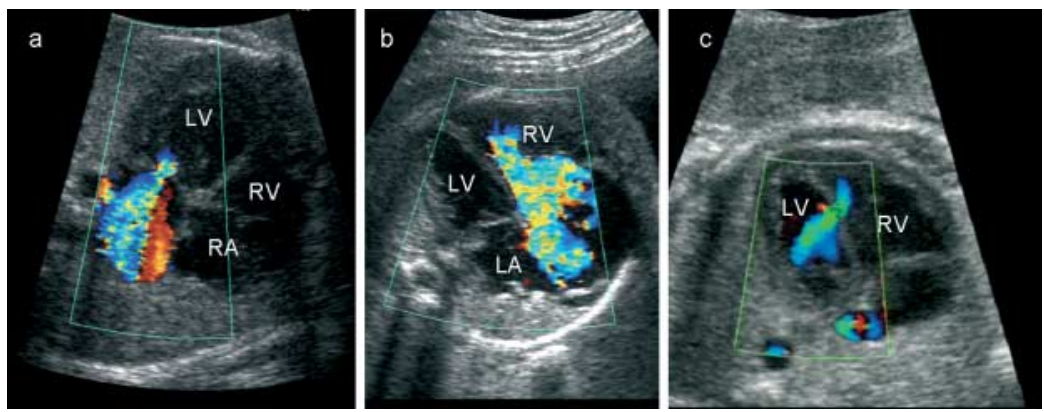

Abb. 9 a-c Auffällige Farbdoppler-Befunde im Vier-Kammer-Blick. a Mitralregurgitation bei einer kritischen Aortenstenose. b Trikuspidalregurgitation mit weit apikalem Ursprung des „Jets“bei einer Ebstein'schen Anomalie. c „Jet“ über das Ventrikelseptum bei einem kleinen muskulären Ventrikelseptum-Defekt (LV, linker Ventrikel; LA, linker Vorhof; RV, rechter Ventrikel; RA, rechter Vorhof). 먼 Video 9a, 먼 Video 9b, ㅁㅁㄴ Video 9c

Fig. 9 a-c Conspicuous colour Doppler findings in four-chamber view. a Mitral regurgitation in the case of a critical aortic stenosis. b Tricuspid regurgitation with a far apical origin of the "jet" in a case of Ebstein's anomaly. c "Jet" over the ventricular septum in the case of a small muscular ventricular septal defect (LV, left ventricle; LA, left atrium; RV, right ventricle; RA, right atrium).

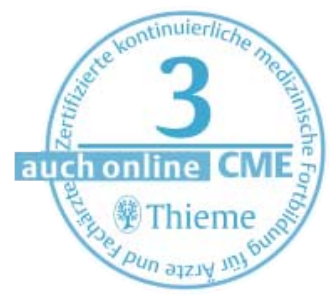

zierten Vitien [20-22]. Unterschieden werden je nach Lokalisation Inlet- (unterhalb der AVKlappen), muskuläre (im trabekulären Septum)

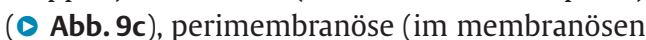
Septum unter der Aortenklappe mit einem variablen muskulären Anteil) und Outlet- (subpulmonal unter der Pulmonalklappe) Ventrikelseptum-Defekte. Im 4KB werden vor allem die größeren muskulären und Inlet-VentrikelseptumDefekte diagnostiziert, während die perimembranösen Defekte nur dann auffallen, wenn sie groß sind und bis in das muskuläre oder InletSeptum hineinreichen. Im B-Bild sind Ventrikelseptum-Defekte ab einer Größe von $2 \mathrm{~mm}$ diagnostizierbar, während die kleineren (meist muskulären) Defekte ( $\bullet$ Abb.9c) nur mithilfe der Farbdoppler-Sonografie dargestellt werden können.

Kleine muskuläre Ventrikelseptum-Defekte sind häufig isolierte Befunde und unterliegen einer hohen spontanen Verschlussrate in den ersten Lebensjahren, während die größeren Defekte im
Ausflusstrakt häufig mit komplexeren kardialen Vitien (Fallot'sche Tetralogie, Double outlet ventricle, Truncus arteriosus communis, unterbrochener Aortenbogen, Transposition der großen Arterien) und Aneuploidien (Trisomie 18 und 13) vergesellschaftet sind [22].

Vorhofseptum-Defekte betreffen vor allem das Septum secundum, sind als isolierte Befunde aufgrund des beim Fetus offenen Foramen ovale pränatal kaum zu diagnostizieren. Defekte des Septum primum sind dagegen meist Teil eines atrioventrikulären Septum-Defektes und können im 4KB diagnostiziert werden. Abzugrenzen ist der isolierte Septum-primum-Defekt von einem erweiterten Sinus coronarius, der meist infolge einer in ihn mündenden links persistierenden oberen Hohlvene auftritt [23].

Atrioventrikuläre Septum-Defekte (AVSD) sind mit 16 - 18\% die am häufigsten pränatal diagnostizierten Herzfehler [20, 21]. Sie umfassen einen Septum-primum-Defekt, einen hochliegenden Ventrikelseptum-Defekt sowie eine gemeinsame AV-Klappe. Im 4KB fällt vor allem in der Diastole das fehlende Herzkreuz auf ( $\bullet$ Abb. 10a). In der Systole ist kein Versatz der Trikuspidalklappe nach apikal nachweisbar, daher wirkt die AVKlappenebene wie eine durchgezogene Linie $(\bullet$ Abb. 10c). In der Farbkodierung fällt in der Diastole über dem fehlenden Herzkreuz oft ein fusionierter Einfluss auf ( $\bullet$ Abb. 10b), während in der Systole häufig eine charakteristische mittig gelegene AV-Klappenregurgitation nachweisbar ist. Atrioventrikuläre Septum-Defekte sind vor allem mit Aneuploidien (Trisomie 21 und 18), Heterotaxie-Syndromen [14] und komplexen Fehlbildungssyndromen assoziiert. Der isolierte atrioventrikuläre Septum-Defekt ist selten [22].

\section{Atrioventrikularklappen}

Anomalien der Trikuspidalklappe machen $6-12 \%$ der pränatal diagnostizierten Vitien aus $[20,21]$.

Die Trikuspidaldysplasie und die Ebstein'sche Anomalie zeichnen sich durch einen dysplastischen und insuffizienten Trikuspidalklappenapparat aus, wobei die Segel verdickt erscheinen. Im 4KB imponiert im B-Bild meist eine ausgeprägte Kardiomegalie mit massiv vergrößertem

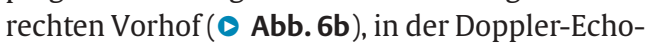
kardiografie eine schwere Trikuspidalklappeninsuffizienz ( $\bullet$ Abb.9b). Bei der Ebstein'schen Anomalie ist der septale Trikuspidalklappenansatz zudem weit nach apikal versetzt, sodass funktionell ein Teil des rechten Ventrikels atrialisiert ist ( $\bullet$ Abb. 6b). Bei der Trikuspidaldysplasie ist der Klappenansatz am Ventrikelseptum in normaler Position [16].

Bei einer Trikuspidalatresie fällt im 4KB üblicherweise eine verdickte echogene und starre Klappe bzw. Membran auf. Der rechte Ventrikel ist größtenteils hypoplastisch und kommuni- 
(- Fig.9c), perimembranous (in the membranous septum below the aortic valve with a variable muscular part) and outlet (subpulmonary, below the pulmonary valve) defects. In the $4 \mathrm{CV}$ above all one can diagnose the larger muscular and inlet ventricular septum defects, whereas the perimembranous defects only become apparent when they are large and extend into the muscular or inlet septum. In B mode images, ventricular septum defects larger than about $2 \mathrm{~mm}$ can be diagnosed whereas smaller (mostly muscular) defects ( $\nabla$ Fig. 9c) can only be visualised with the help of colour Doppler sonography.

Small muscular defects of the ventricular septum are often isolated findings and are subject to a high spontaneous closure rate in the first years of life, whereas larger defects in the outflow tract are frequently accompanied by complex cardiac defects (tetralogy of Fallot, double outlet ventricle, common truncus arteriosus, interrupted aortic arch, transposition of the great arteries) and aneuploidy (trisomy 18 and 13) [22].

Atrial septal defects affect above all the septum secundum, and can hardly be diagnosed as isolated findings prenatally due to the open foramen ovale in fetuses. Defects of the septum primum, on the other hand, are mostly part of an atrioventricular septum defect and can be detected in $4 \mathrm{CV}$. An isolated septum primum defect can be mimicked by a dilated coronary sinus which mostly occurs as a result of the insertion of a left persistent superior vena cava [23].

Atrioventricular septal defects (AVSD) with an incidence of $16-18 \%$ are the most frequently prenatally identified cardiac defects $[20,21]$. They encompass a septum primum defect, an inlet ventricular septal defect as well as a common atrioventricular valve. In the $4 \mathrm{CV}$, above all in the diastole, the absence of a "heart cross" is conspicuous ( $\bullet$ Fig. 10a). In the systole no shift of the tricuspid valve to apical can be detected, thus the AV valve plane appears as an unbroken line ( Fig. 10c). In colour-coded images in the diastole a fused inflow above the absent "heart cross" is noted ( $\bullet$ Fig. 10b), whereas in the systole a characteristic centrally located AV valve insufficiency is often detectable. Atrioventricular septum defects ara associated, above all, with aneuploidy (trisomy 21 und 18), heterotaxia syndromes [14] and complex malformation syndromes. An isolated atrioventricular septum defect is a rare occurrence [22].

\section{Atrioventricular valves}

Anomalies of the tricuspid valve account for 6$12 \%$ of the prenatally diagnosed cardiac defects [20, 21].

Tricuspid dysplasia and Ebstein's anomaly are characterised by a dysplastic and insufficient tricuspid valve apparatus in which the velum appears to be thickened. In the $4 \mathrm{CV}$ in B mode,
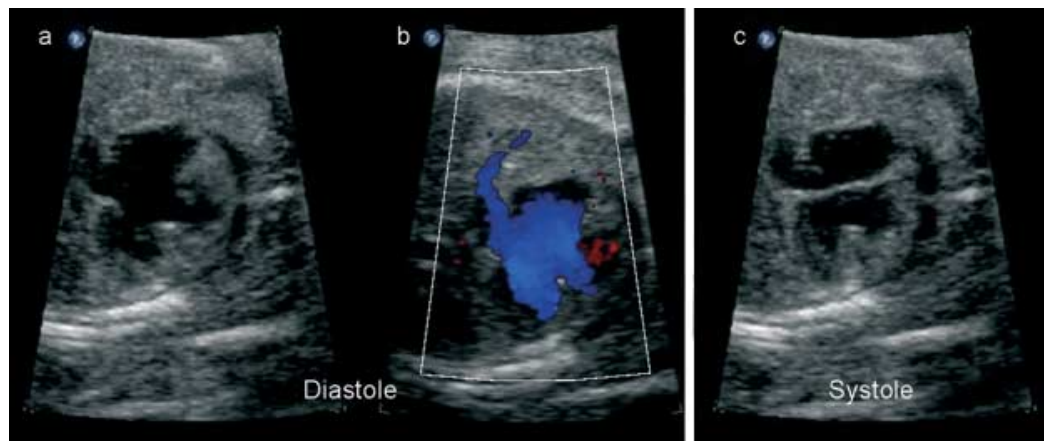

Fig. 10 a-c Atrioventricular septum defect in four-chamber view. In the diastole in B mode image a the absence of the "heart cross" is remarkable, in the colour-coded image $\mathbf{b}$ the common inflow (coded blue) into both ventricles is apparent. In the systole no displacement of the tricuspid valve to caudal can be detected, thus the AV valve plane appears as an unbroken line $\mathbf{c}$. 먼 Video 10a, 먼 Video 10b

Abb. 10 a-c Atrioventrikulärer Septum-Defekt im Vier-Kammer-Blick. In der Diastole fällt im B-Bild a das fehlende Herzkreuz auf, in der Farbkodierung b der gemeinsame Einfluss (blau kodiert) in beide Ventrikel. In der Systole ist kein Versatz der Trikuspidalklappe nach apikal nachweisbar, daher wirkt die AV-Klappenebene wie eine durchgezogene Linie c.
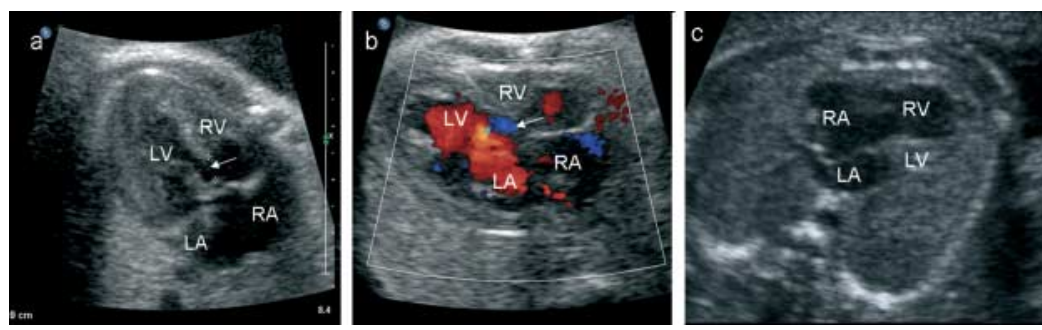

Fig. 11 a-c Anomalies of the atrioventricular valves in four-chamber view. a Tricuspid atresia. Conspicuous are the thickened, echogenic valves, the hypoplastic right ventricle (RV) and the ventricular septal defect (arrow). In colour Doppler sonography b only the inflow into the left ventricle (LV) and the right-left shunt (coded blue, arrow) over the septal defect into the rudimentary right ventricle (RV) can be visualised. c Hypoplastic left heart in the case of a mitral atresia. The lumen of the left ventricle (LV) is completely absent and the right ventricle (RV)

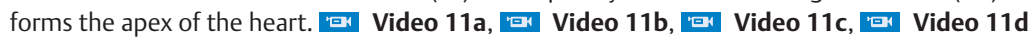
Abb. 11 a-c Anomalien der Atrioventrikularklappen im Vier-Kammer-Blick. a Trikuspidalatresie. Auffällig sind die verdickte echogene Klappe, der hypoplastische rechte Ventrikel (RV) und der Ventrikelseptum-Defekt (Pfeil). In der Farbdoppler-Sonografie b lässt sich lediglich der Einfluss in den linken Ventrikel (LV) und der Links-Rechts-Shunt (blau kodiert, Pfeil) über den Septum-Defekt in den rudimentären rechten Ventrikel (RV) darstellen. c Hypoplastisches Linksherz im Rahmen einer Mitralatresie. Das Lumen des linken Ventrikels (LV) fehlt völlig und der rechte Ventrikel (RV) bildet die Herzspitze.

a pronounced cardiomegaly is remarkable with massively enlarged right atrium ( Fig. 6 b). In Doppler echocardiography a severe tricuspid valve insufficiency ( Fig. 9b) can be visualized. In Ebstein's anomaly the insertion of the septal tricuspid valve is displaced far to apical so that functionally a part of the right ventricle is atrialised ( $\bullet$ Fig. 6 b). In tricuspid dysplasia the valve's insertion on the ventricular septum is in the normal position [16].

In tricuspid atresia a thickened, echogenic and rigid valve or, respectively, membrane is usually conspicuous in $4 \mathrm{CV}$. The right ventricle is generally hypoplastic and communicates over an almost always present ventricular septum defect with the left ventricle ( $\bullet$ Fig.11a). In colour Doppler sonography merely the inflow into the left ventricle and the left-right shunt over 

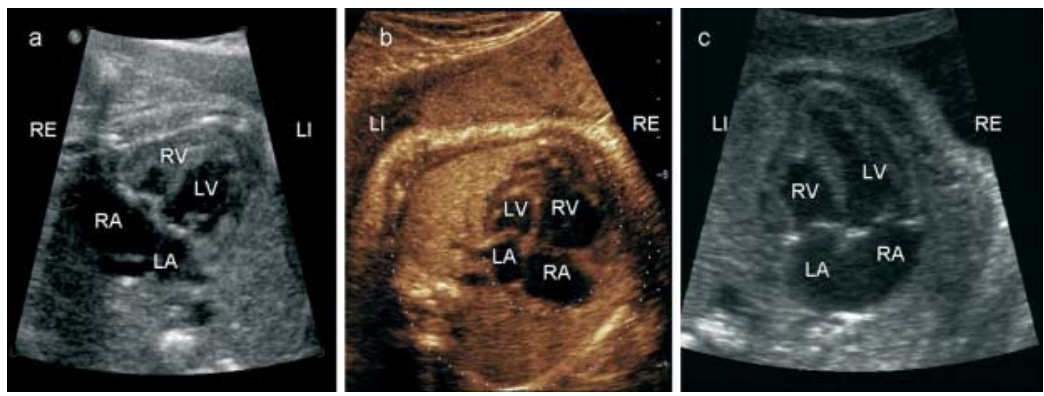

Abb. 12 a-c Auffällige Ventrikelmorphologie im Vier-Kammer-Blick. a Hypoplastischer rechter Ventrikel (RV) bei einer Pulmonalatresie mit intaktem Ventrikelseptum. Der rechte Ventrikel ist klein und echogen. b Hypoplastischer linker Ventrikel (LV) bei einer kritischen Aortenstenose. Der linke Ventrikel ist klein und nicht mehr spitzenbildend. c Atrioventrikuläre Diskordanz (Ventrikelinversion) bei einem Fetus mit korrigierter Transposition der großen Gefäße (ventrikuloarterielle Diskordanz). Der rechte Vorhof (RA) ist mit dem rechts liegenden linken Ventrikel (LV) verbunden, der linke Vorhof (LA) mit dem links liegenden rechten Ventrikel (RV). 만 Video 12a, 먼 Video 12b, 맘 Video 12c

Fig. 12 a-c Conspicuous ventricular morphology in four-chamber view. a Hypoplastic right ventricle (RV) in a case of pulmonary atresia with intact ventricular septum. The right ventricle is small and echogenic. b Hypoplastic left ventricle (LV) in a case of critical aortic stenosis. The left ventricle is small and no longer forms the apex. c Atrioventricular discordance (ventricular inversion) in a fetus with corrected transposition of the great vessels (ventriculoarterial discordance). The right atrium (RA) is joined with the right-located left ventricle (LV), the left atrium (LA) is joined with the left-located right ventricle (RV).

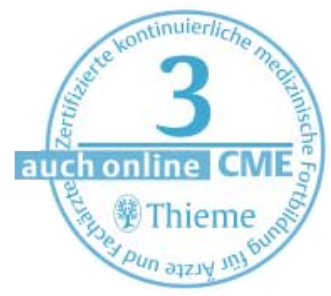

ziert über einen fast immer vorhandenen Ventrikelseptum-Defekt mit dem linken Ventrikel

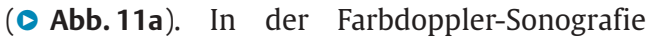
lässt sich lediglich der Einfluss in den linken Ventrikel und der Links-rechts-Shunt über den Septum-Defekt in den hypoplastischen rechten Ventrikel darstellen ( $\bullet$ Abb. 11b).

Eine Mitralatresie ohne Aortenatresie ist extrem selten; bei zusätzlichem Ventrikelseptum-Defekt kann dann der linke Ventrikel nur geringfügig verkleinert sein. Zumeist liegt jedoch eine Kombination von Aorten- und Mitralatresie vor, die schon früh in der Schwangerschaft zu einer schweren linksventrikulären Hypoplasie führt (s.u.).

\section{Ventrikelmorphologie}

Vitien, die durch sekundäre Veränderungen der Ventrikelmorphologie oder durch auffällige Blutflüsse im 4KB auffallen, aber erst in den Ausflusstraktschnittebenen eindeutig diagnostiziert werden können, betreffen vor allem die Semilunarklappen (Aorten- oder Pulmonalklappe) und die Ausflusstraktgefäße.

Pulmonalatresien und oft auch Pulmonalstenosen sind meist mit einem perimembranösen Ventrikelseptum-Defekt assoziiert und verändern dann den Aspekt des 4KB nicht. In den selteneren Fällen einer Pulmonalatresie oder schweren Pulmonalstenose mit intaktem interventrikulären Septum kommt es zunächst zu einer rechtsventrikulären Wandhypertrophie und Dysfunktion und im weiteren Verlauf zu unterschiedlichen Graden einer Hypoplasie, die dann im 4KB auffällt ( $\bullet$ Abb.12a). In der Farbdoppler-Sonografie lässt sich in den Fällen mit Pulmonalatresie und hochgradigen Stenosen mit intaktem interventrikulären Septum meist eine

holosystolische Trikuspidalregurgitation nachweisen. Der rechte Vorhof kann dabei dilatiert sein. In einigen Fällen lassen sich im 4KB auch ventrikulokoronare Kommunikationen durch die Farbdoppler-Echokardiografie nachweisen [24].

Aortenatresien gehen in den meisten Fällen mit einem intakten Ventrikelseptum einher und sind daher regelmäßig mit einer schweren Hypoplasie des linken Ventrikels assoziiert. Dieser ist bei zusätzlicher Mitralatresie kaum darstellbar ( Abb. 11c), wobei der Einfluss in den linken Ventrikel fehlt. Bei einer Aortenatresie mit offener (immer dysplastischer) Mitralklappe lassen sich Einfluss und Insuffizienz der Mitralklappe nachweisen. Der linke Ventrikel ist ebenfalls hypoplastisch und weist oft eine Endokardfibroelastose auf.

Die schwere Aortenstenose führt nach einer initialen Wandhypertrophie zu einer zunehmenden Dysfunktion und Dilatation des linken Ventrikels. Meist liegt eine Mitralinsuffizienz vor ( Abb.9a). Dann kommt es zu einer sonografisch nachweisbaren Endokardfibroelastose, zunächst im Bereich der Papillarmuskeln, des interventrikulären Septums und schließlich des gesamten Ventrikels. Im weiteren Verlauf wird der linke Ventrikel zunehmend hypoplastisch und nicht mehr spitzenbildend ( Abb. 12b). Der Endpunkt der intrauterinen Entwicklung ist bei den meisten Aortenatresien und kritischen Stenosen somit das hypoplastische Linksherz, das in Abhängigkeit von der Schwere der Obstruktion und der linksventrikulären Reserven bereits im frühen zweiten Trimenon vorliegt oder sich erst im weiteren Schwangerschaftsverlauf entwickeln kann [25]. Das hypoplastische Linksherz macht 14-16\% der pränatal diagnostizierten Herzfehler aus [26].

Leichtere Aortenstenosen können in einigen Fällen zu einer linksventrikulären Wandhypertrophie führen, in anderen Fällen aber auch zu keinen Veränderungen des $4 \mathrm{~KB}$.

Auch Aortenisthmusstenosen können den Aspekt des $4 \mathrm{~KB}$ verändern. Charakteristisch ist hier der schmale, aber fast immer spitzenbildende linke Ventrikel. Dies manifestiert sich bei zunehmender Stenose bereits im 2. Trimenon. Leichtere Stenosen, aber auch Feten mit normalem Aortenbogen können in der Spätschwangerschaft einen linken Ventrikel aufweisen, der deutlich schmaler als der rechte ist [26].

Differenzialdiagnostisch sollte bei einem auffälligen 4KB mit nicht spitzenbildendem linken Ventrikel aber auch die seltene Ventrikelinversion (atiroventrikuläre Diskordanz) in Betracht gezogen werden. Hier liegt der spitzenbildende morphologisch linke Ventrikel rechts (also thoraxwandnah) und der morphologisch rechte Ventrikel mit dem Moderatorband links ( Abb. 12c). In diesen Fällen liegen oft Heterotaxie-Syndrome 
the septal defect in the hypoplastic right ventricle can be visualised ( $\bullet$ Fig. 11b).

Mitral atresia without aortic atresia is very rare; in the case of an additional ventricular septum defect the left ventricle may then only be slightly reduced in size. However, a combination of aortic and mitral atresia is mostly found which, early in the pregnancy leads to a severe left ventricular hypoplasia (see below).

\section{Ventricular Morphology}

Defects that become noticeable in $4 \mathrm{CV}$ through secondary changes of ventricular morphology or through conspicuous blood flows but which can only be unambiguously diagnosed in the plane of the outflow tract sections affect above all the semilunar valves (aortic or pulmonary valves) and the outflow tract vessels.

Pulmonary atresias and pulmonary stenoses are mostly associated with a perimembranous ventricular septal defect and thus do not change the aspect of $4 \mathrm{CV}$. In the rare cases of a pulmonary atresia or severe pulmonary stenosis with an intact interventricular septum, there is at first a right ventricular wall hypertrophy followed in the further course by different grades of hypoplasia that are then conspicuous in the 4CV ( Fig. 12a). By colour Doppler sonography in those cases with pulmonary atresia and highgrade stenoses with intact interventricular septum, a holosystolic tricuspid regurgitation can usually be detected. The right atrium can be dilated thereby. In some cases ventriculocoronary communication can be identified in $4 \mathrm{CV}$ by colour Doppler echocardiography [24].

Aortic atresias occur in most cases together with an intact ventricular septum and thus are regularly ssociated with a severe hypoplasia of the left ventricle. In cases of additional mitral atresia this can hardly be visualised ( $\bullet$ Fig. 11c), and also inflow into the left ventricle is absent. In the case of an aortic atresia with open (always dysplastic) mitral valve, the inflow and insufficiency of the mitral valve can be demonstrated. The left ventricle is also hypoplastic and often exhibits an endomyocardial fibroelastosis.

After the initial wall hypertrophy, a severe aortic stenosis leads to an increasing dysfunction and dilatation of the left ventricle. There is usually a mitral insufficiency ( $\bullet$ Fig. 9a). A sonographically detectable endomyocardial fibroelastosis then follows, firstly in the region of the papillary muscles, the intraventricular septum and finally in the entire ventricle. In the further course, the left ventricle becomes increasingly hypoplastic and no longer forms the apex ( $\bullet$ Fig. 12b). In most cases of aortic atresias and critical stenoses, the end point of the interuterine development is thus a hypoplastic left heart which, depending on the severity of the obstruction and the left ventricular reserves, can develop early in the sec- ond trimester or during the further course of the pregnancy [25]. The hypoplastic left heart accounts for $14-16 \%$ of all prenatally diagnosed heart defects [26].

In some cases, mild aortic stenoses can lead to a left ventricular wall hypertrophy, in others however to no changes in the $4 \mathrm{CV}$.

Coarctation of the aorta can also change the aspect of $4 \mathrm{CV}$. Characteristic hereby is the narrow but always apex-forming left ventricle. This manifests with increasing stenosis already in the $2^{\text {nd }}$ trimester. However, not only those with mild coarctation but also fetuses with normal aortic arches can, in late pregnancy, exhibit a left ventricle that is markedly narrower than the right one [26].

In cases of a conspicuous $4 \mathrm{CV}$ with a non-apexforming left ventricle, the rare ventricular inversion (atrioventricular discordance) should be included in the differential diagnosis. In such a case the apex-forming, morphological left ventricle lies on the right (i.e., near the thorax wall) and the morphological right ventricle with moderator band is on the left ( $\bullet$ Fig. 12c). In these cases heterotaxia syndromes with further complex cardiac defects are frequently present $[14$, 27, 28].

Defects that do not change the aspect of the $4 \mathrm{CV}$ and which thus can only be diagnosed in the five-chamber and three-vessel view, include tetralogy of Fallot, double outlet right ventricle, common truncus arteriosus and transposition of the great vessels. These defects are only conspicuous in $4 \mathrm{CV}$ when they are associated with a large ventricular septal defect that extends into the muscular part of the septum.

\section{Vessels behind the heart}

Also a glance behind the heart in $4 \mathrm{CV}$ gives important signs about the presence of heart defects. Here attention should be paid above all to the number of vessels and their sidewise arrangement. In the physiological state there is only one vessel behind the heart on the left side, the descending aorta. If there is another equally large vessel behind the heart it is mostly an enlarged azygos vein that occurs together with aplasia of the hepatic segment of the inferior vena cava (๑ Fig. 13a). This vascular anomaly occurs almost exclusively in heterotaxia syndromes and is regularly accompanied by complex cardiac defects [27]. Less commonly there is a pulmonary venous confluence of a total anomalous infracardiac pulmonary venous connection which is also frequently accompanied by heteroraxia syndromes (0 Fig. 13b) [28]. If the descending aorta lies to the right of the spinal column in levocardia, there is a right aortic arch, which is not only an isolated occurrence but also present in up to $35 \%$ of fetuses with tetralogy of Fallot, pulmonary atresia with ventricular septum defect, and common arterial trunk ( $\odot$ Fig. 13c) [29].

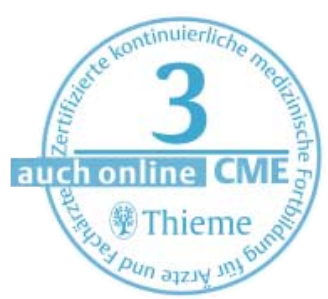



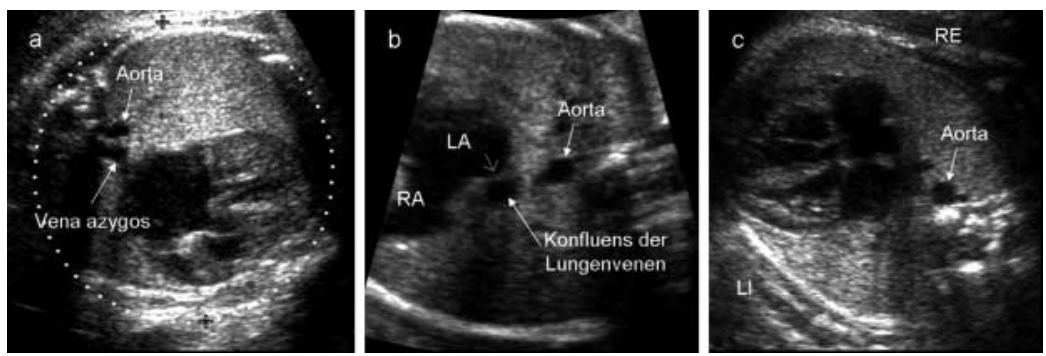

Abb. 13 a-c Auffällige Befunde dorsal des Vier-Kammer-Blickes. a Azygoskontinuität der unterbrochenen V. cava inferior im Rahmen eines Heterotaxie-Syndroms. Hinter dem Herzen findet sich eine verbreiterte V. azygos als zweites großes Gefäß neben der deszendierenden Aorta. b Totale infrakardiale Lungenvenenfehlmündung im Rahmen eines Heterotaxiesyndroms. Hinter dem Herzen findet sich der pulmonalvenöse Konfluens als überzähliges Gefäß neben der deszendierenden Aorta in unmittelbarer Nähe zum linken Vorhof (LA). c Rechts deszendierende Aorta im Rahmen einer Fallot'schen Tetralogie mit rechtem Aortenbogen. 머 Video 13a,

\section{回 Video 13b, 回 Video 13c}

Fig. 13 a-c Conspicuous dorsal findings in the four-chamber view. a Azygos continuity of the interrupted inferior vena cave in a case of heterotaxy cava syndrome. Behind the heart there is a broadened azygos vein as second large vessel besides the descending aorta. $\mathbf{b}$ total anomalous infracardiac pulmonary venous connection in a case of heterotaxy syndrome. The pulmonary venous confluence is located behind the heart as a supernumary vessel beside the descending aorta in the direct vicinity of the left atrium (LA). $\mathbf{c}$ Right descending aorta in a case of the tetralogy of Fallot with a right aortic arch.

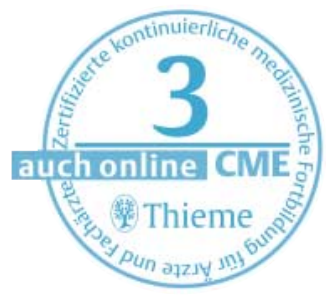

mit weiteren komplexen kardialen Vitien vor [14, $27,28]$.

Vitien, die den Aspekt des 4KB nicht verändern und somit nur im Fünf-Kammer-Blick und im Drei-Gefäß-Blick diagnostiziert werden können, sind Fallot'sche Tetralogie, Double outlet right ventricle, Truncus arteriosus communis und Transposition der großen Gefäße. Diese Vitien fallen im $4 \mathrm{~KB}$ nur auf, wenn sie mit einem großen Ventrikelseptum-Defekt assoziiert sind, der dann den im 4KB dargestellten Septumanteil mit erfasst.

\section{Gefäße hinter dem Herzen}

Auch der Blick hinter das Herz im 4KB gibt wichtige Hinweiszeichen auf das Vorliegen von Herzfehlern. Hierbei sollte die Aufmerksamkeit vor allem der Anzahl der Gefäße und der Seitenzuordnung gelten. Physiologischerweise verläuft hinter dem Herz nur ein Gefäß auf der linken Seite: die Aorta descendens. Findet sich hinter dem Herzen ein weiteres gleich großes Gefäß, handelt es sich meist um eine verbreiterte Vena azygos im Rahmen einer Aplasie des hepatischen Segments der Vena cava inferior $(\circlearrowleft$ Abb. 13a). Diese Gefäßanomalie kommt fast ausschließlich bei HeterotaxieSyndromen vor und ist regelmäßig mit komplexen kardialen Vitien vergesellschaftet [27]. Seltener handelt es sich um den pulmonalvenösen Konfluens einer totalen infrakardialen Lungenvenenfehlmündung, die ebenfalls häufig mit Heterotaxie-Syndromen vergesellschaftet ist ( $\bigcirc$ Abb. 13b) [28]. Verläuft bei Laevokardie die deszendierende Aorta rechts der Wirbelsäule, liegt ein rechter Aortenbogen vor, der isoliert vorkommt, aber auch in bis zu $35 \%$ der Feten mit Fallot'scher Tetralogie, Pulmona-

latresie mit Ventrikelseptum-Defekt und Truncus arteriosus communis vorliegt ( $\odot$ Abb. 13c) [29].

\section{Der Vier-Kammer-Blick im ersten Trimenon \\ $\nabla$}

Mit zunehmender Expertise der Untersucher und Benutzung von hochauflösenden Ultraschallgeräten ist die fetale Echokardiografie an ausgewählten Zentren zum festen Bestandteil der frühen Fehlbildungsdiagnostik geworden. Dabei hat sich der Untersuchungszeitraum zwischen $12+0$ und $13+6$ SSW als optimaler Zeitpunkt erwiesen. Die Untersuchung kann transabdominal oder transvaginal erfolgen [30]. Je früher der Untersuchungszeitpunkt gewählt wird, umso häufiger ist mit einer eingeschränkten Beurteilbarkeit der noch kleinen kardialen Strukturen (Herzdurchmesser mit 13 SSW ca. $7 \mathrm{~mm}$ ) zu rechnen. Die transvaginale Untersuchungstechnik bietet zwar den Vorteil der besseren B-Bild-Auflösung ( $\bullet$ Abb.3a), hat aber den Nachteil der schlechteren Bewegungsfreiheit bei der Einstellung der verschiedenen Schnittebenen. Die Zuhilfenahme der farbkodierten Doppler-Sonografie ( $\bullet$ Abb. $\mathbf{3 b}$ ) unterstützt die Visualisierung und Beurteilung der einzelnen kardialen Strukturen im ersten Trimenon und verkürzt somit die Untersuchungszeit [30]. Die beiden häufigsten Indikationen zur frühen fetalen Echokardiografie betreffen Schwangerschaften mit familiärem Risiko und Feten mit einer erweiterten Nackentransparenz. Bei der erstgenannten Risikogruppe (Wiederholungsrisiko ca. 2-3\%) geht es in erster Linie um die Beruhigung und Rückversicherung, dass eine weitestgehend normale kardiale Anatomie vorliegt. In der zweiten Risikogruppe steigt die Prävalenz von Herzfehlern mit zunehmender Nackentransparenz exponentiell an [31]. Sie lag bei euploiden Feten mit einer NT bis $3,4 \mathrm{~mm}$ (>95. Perzentile) bei $1,8 \%$, mit einer NT von $3,5-4,4 \mathrm{~mm}$ bei $3,5 \%$ und mit einer NT von $4,5-5,4 \mathrm{~mm}$ bei $6,4 \%$. Damit ist die Prävalenz von Herzfehlern im Kollektiv der Feten mit einer NT $>3,5 \mathrm{~mm}$ höher als in Familien mit einer anamnestischen Belastung. Eine Trikuspidalinsuffizienz im ersten Trimenon ( $\boldsymbol{O} \mathbf{A b b} . \mathbf{3 c}$ ) erhöht bei Feten mit erweiterter Nackentransparenz zusätzlich das Aneuploidierisiko und das Risiko für das Vorliegen kardialer Vitien [32].

Die Entdeckungsrate fetaler Herzfehler hängt wie im zweiten Trimenon in erster Linie vom Ausbildungsstand des Untersuchers, von der Lage des Fetus sowie der Komplexität der Untersuchung ab. Publizierte Studien betreffen überwiegend Daten zu Hoch-Risiko-Kollektiven, in denen Feten mit erweiterter Nackentransparenz und/oder Aneuploidie überrepräsentiert sind. Dabei werden bei vollständiger echokardiografi- 


\section{The Four-Chamber View in the First Semester \\ $\nabla$}

With increasing experience of the examine and the use of high-resolution sonographic systems, fetal echocardiography has become an integrated component of first trimester malformation screening in selected centres. An examination between the $12+0$ and the $13+6$ week of pregnancy has thereby proved to be optimal. The examination can be performed in the transabdominal or the transvaginal technique [30]. The earlier the time point of the examination is chosen the more often is a only limited evaluability of the still small cardiac structures (heart diameter in the $13^{\text {th }}$ week of pregnancy ca. $7 \mathrm{~mm}$ ) to be expected. Although it offers the advantage of better $B$ mode resolution ( $\bullet$ Fig. $3 a$ ), the transvaginal examination technique has the disadvantage of the poorer mobility when addressing the various cross-sectional planes. The additional use of colour-coding ( $\bullet$ Fig. 3b) supports the visualisation and evaluation of the individual cardiac structures in the first trimester and thus shortens the examination time [30]. The two most common indications for early fetal echocardiography involve pregnancies with a familial risk and fetuses with an increased nuchal translucency. In the former risk group (risk of repetition ca. 2 $3 \%$ ) it is a matter of assuagement and confirmation that an as normal as possible cardiac anatomy is present. In the latter risk group, the incidence of heart defects increases exponentially with increasing nuchal translucency [31]. In euploid fetuses with an NT of up to $3.4 \mathrm{~mm}$ ( $>95$ th percentile) it is $1.8 \%$, with an NT of $3.5-4.4 \mathrm{~mm}$ $3.5 \%$ and with an NT of $4.5-5.4 \mathrm{~mm} 6.4 \%$. Thus the prevalence of heart defects in the collective of fetuses with an NT $>3.5 \mathrm{~mm}$ is higher than that in familes with an anamnestic predisposition. A tricuspid insufficiency in the frist trimester ( Fig. 3c) additionally increases the risk of aneuploidy and the risk for the presence of cardiac defects in fetuses with an increased nuchal translucency [32].

The detection rate for fetal heart defects depends, as in the second trimester, first of all on the degree of experience of the examiner, on the position of the fetus and on the complexity of the examination. Published studies mainly concern data on high-risk collectives in which fetuses with increased nuchal translucency and/or aneuploidy are over represented. Here, detection rates of between $63 \%$ and $70 \%$ are given for complete echcardiographic examina- tions with consideration of the outflow tracts [33]. With a detection rate of ca. $50 \%$, atriventricular septal defects are the most frequently diagnosed heart defects in these series [32, 33]. Isolated defects of the ventricular septum or the outflow tracts are much less commonly diagnosed correctly in the first trimester. Becker and Wegner reported for a collective of medium risk ( $54 \%>35$ years) that the detection rate for heart defects in fetuses with an NT $<2.5 \mathrm{~mm}$ was markedly poorer (38\%) than that for fetuses with an NT > $2.5 \mathrm{~mm}$ (97\%) [34]. In marked contrast to these excellent results reported by a few centres for $1^{\text {st }}$ trimester fetal echocardiography are the low detection rates of examinations for the routine screening in low-risk collectives by less experienced examiners. In a Swedish multicentre study with 18,148 first trimester examinations including measurement of $\mathrm{NT}$, the $4 \mathrm{CV}$ could not be correctly set-up in $43 \%$ of the fetuses; the detection rate of fetal heart defects was correspondingly low (11\%) [35].

At the present time it thus appears that the performance of early fetal echocardiography is only meaningful and realisable in specialised centres and for pregnant women with appropriate indications. However, early fetal echocardiography does not replace examinations around the $20^{\text {th }}$ week of pregnancy but should be conducted in combination with them.

\section{Summary}

$\nabla$

Since only a portion of the fetuses with congenital heart defects belong to a risk collective, the prenatal diagnosis of such defects can only be achieved by a general screening. The acquisition of the four-chamber view in B mode sonography is suitable as a minimal variant. With increasing experience by the examiner, the correct visualisation will be achieved more frequently, especially with good ultrasound equipment and a gestational age $>20$ weeks. If conspicuous findigs are seen in the four-chamber view or if this cannot be acquired in adequate quality, there is an indication for further fetal echodardiography which must then include the planes of the outflow tract sections and colour coding. When the examination is limited to acquisition of the fourchamber view, it must be expected that a portion of the critical heart defects will not be recognised.

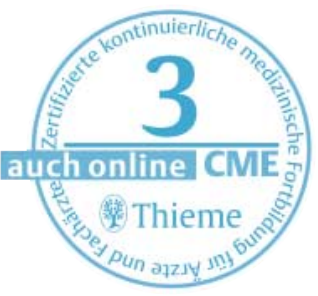


scher Untersuchung unter Einbeziehung der Ausflusstrakte Entdeckungsraten zwischen 63\% und $70 \%$ angegeben [33]. Der in diesen Serien mit ca. 50\% am häufigsten diagnostizierte Herzfehler ist der atrioventrikuläre Septum-Defekt $[32,33]$. Deutlich seltener werden im ersten Trimenon isolierte Septum- oder Ausflusstraktdefekte korrekt diagnostiziert. Becker und Wegner berichteten in einem Kollektiv mit mittlerem Risiko ( $54 \%>35$ Jahre), dass die Detektionsrate für Herzfehler bei Feten mit einer NT $<2,5 \mathrm{~mm}$ deutlich schlechter (38\%) als bei Feten mit einer NT > 2,5 mm (97\%) [34]. In deutlichem Kontrast zu den hervorragenden Ergebnissen, die einige wenige Zentren für die fetale Ersttrimesterechokardiografie aufweisen, stehen die niedrigen Detektionsraten der Untersuchungen zum Routinescreening in Low-risk-Kollektiven durch weniger erfahrene Untersucher. In einer schwedischen Multicenterstudie mit 18148 Ersttrimesteruntersuchungen inklusive NT-Messung konnte der $4 \mathrm{~KB}$ bei $43 \%$ der Feten nicht korrekt eingestellt werden; entsprechend niedrig (11\%) lag die Entdeckungsrate fetaler Herzfehler [35]. Zum gegenwärtigen Zeitpunkt erscheint daher die Durchführung einer frühen fetalen Echokardiografie nur an spezialisierten Zentren und bei Schwangeren mit entsprechender Indikation sinnvoll und realisierbar. Die frühe fetale Echokardiografie ersetzt jedoch auch dann nicht die Untersuchung mit 20 SSW, sondern sollte immer mit ihr kombiniert werden.

\section{Zusammenfassung}

Da nur ein Teil der Feten mit einem kongenitalen Herzfehler einem Risikokollektiv angehört, kann deren pränatale Diagnose nur durch ein generelles Screening erreicht werden. Als Minimalvariante eignet sich dazu die Einstellung des Vier-Kammer-Blickes im B-Bild. Mit zunehmender Erfahrung des Untersuchers gelingt die korrekte Einstellung häufiger, insbesondere bei guter Gerätequalität und einem Gestationsalter $>20$ SSW. Finden sich Auffälligkeiten im VierKammer-Blick oder kann dieser nicht adäquat eingestellt werden, ist die Indikation zu einer weiterführenden fetalen Echokardiografie gegeben, die dann die Ausflusstraktschnittebenen und die Farbkodierung einbeziehen muss. Bei Limitierung der Untersuchung auf die Einstellung des Vier-Kammer-Blickes wird allerdings in Kauf genommen, dass auch ein Teil der kritischen Herzfehler pränatal nicht erkannt wird.
1 Gembruch U, Geipel A. Indications for fetal echocardiography: screening in low- and high-risk populations. In: Yagel S, Silverman NH, Gembruch U (Hrsg). Fetal cardiology. London: Martin Dunitz, 2003: 89-106

2 Yates RS. The influence of prenatal diagnosis on postnatal outcome in patients with structural congenital heart disease. Prenat Diagn 2004; 24: 1143-1149

3 Kumar RK, Newburger JW, Gauvreau Ket al. Comparison of outcome when hypoplastic left heart syndrome and transposition of the great arteries are diagnosed prenatally versus when diagnosis of these two conditions is made only postnatally. Am J Cardiol 1999; 83: 1649-1653

4 Tworetzky W, Wilkins-Haug L, Jennings RW et al. Balloon dilation of severe aortic stenosis in the fetus: potential for prevention of hypoplastic left heart syndrome: candidate selection, technique, and results of successful intervention. Circulation 2004; 110: 2125-2131

5 Garne E, Loane M, Dolk H et al. Prenatal diagnosis of severe structural congenital malformations in Europe. Ultrasound Obstet Gynecol 2005; 25: 6-11

6 Eichhorn K, Schramm T, Bald R et al. Qualitätsanforderungen an die DEGUM-Stufe I bei der geburtshilflichen Ultraschalldiagnostik im Zeitraum 19 bis 22 Schwangerschaftswochen. Ultraschall in Med 2006; 27: $185-187$

7 Chaoui $R$. The four-chamber view: four reasons why it seems to fail in screening for cardiac abnormalities and suggestions to improve detection rate. Ultrasound Obstet Gynecol 2003; 22: 3-10

8 Tegnander E, Williams W, Johansen OJ et al. Prenatal detection of heart defects in a non-selected population of 30149 fetuses - detection rates and outcome. Ultrasound Obstet Gynecol 2006; 27: 252-265

9 Merz E, Eichhorn K, Hansmann M et al. Qualitätsanforderungen an die weiterführende differenzialdiagnostische Ultraschalluntersuchung in der pränatalen Diagnostik (DEGUM-Stufe II) im Zeitraum 18 bis 22 Schwangerschaftswochen. Ultraschall in Med 2002; 23: 11-12

10 Achiron R, Glaser J, Gelernter I et al. Extended fetal echocardiographic examination for detecting cardiac malformations in low risk pregnancies. BMJ 1992; 304: 671-674

11 Stümpflen I, Stümpflen A, Wimmer M et al. Effect of detailed fetal echocardiography as part of routine prenatal ultrasonographic screening on detection of congenital heart disease. Lancet 1996; 348: 854-857

12 Chaoul R, Heling KS. Grundlagen der 3D- und 4DEchokardiographie beim Fetus unter Nutzung der Spatio-Temporal-Image-Correlations (STIC)-Software. Ultraschall in Med 2006; 27: 340-346

13 Yagel S, Cohen SM, Shapiro I et al. 3D and 4D ultrasound in fetal cardiac scanning: a new look at the fetal heart. Ultrasound Obstet Gynecol 2007; 29: 81-95

14 Berg C, Geipel A, Smrcek J et al. Prenatal diagnosis of cardiosplenic syndromes: a 10-year experience. Ultrasound Obstet Gynecol 2003; 22: 451-459

15 Bernasconi A, Azancot A, Simpson JM et al. Fetal dextrocardia: diagnosis and outcome in two tertiary centres. Heart 2005; 91: 1590-1594

16 Gembruch U, Kohl T, Geipel A et al. Ebstein-Anomalie des Fetus. Gynakologe 2006; 39: 39-47

17 Gembruch U, Smrcek JM. The prevalence and clinical significance of tricuspid valve regurgitation in normally grown fetuses and those with intrauterine growth retardation. Ultrasound Obstet Gynecol 1997; 9: 374-382 
18 Berg C, Geipel A, Kohl T et al. Atrioventricular block detected in fetal life: associated anomalies and potential prognostic markers. Ultrasound Obstet Gynecol 2005; 26: 4-15

19 Gembruch U. Fetal tachyarrhythmia. In: Yagel S, Silverman NH, Gembruch U (Hrsg). Fetal Cardiology. London: Martin Dunitz, 2003: 355-373

20 Fesslova V, Nava S, Villa L. Evolution and long term outcome in cases with fetal diagnosis of congenital heart disease: Italian multicentre study. Fetal Cardiology Study Group of the Italian Society of Pediatric Cardiology. Heart 1999; 82: 594-599

21 Allan LD, Sharland GK, Milburn A et al. Prospective diagnosis of 1006 consecutive cases of congenital heart disease in the fetus. J Am Coll Cardiol 1994; 23: $1452-1458$

22 Birk E, Silverman NH. Intracardiac shunt malformations. In: Yagel S, Silverman NH, Gembruch U (Hrsg). Fetal Cardiology. London: Martin Dunitz, 2003: 201-210

23 Berg C, Knüppel M, Geipel A et al. Prenatal diagnosis of persistent left superior vena cava and its associated congenital anomalies. Ultrasound Obstet Gynecol 2006; 27: 274-280

24 Baschat A, Gembruch U. Examination of the fetal coronary circulation. In: Yagel S, Silverman NH, Gembruch U (Hrsg). Fetal Cardiology. London: Martin Dunitz, 2003: 299-312

25 Axt-Fliedner R, Kreiselmaier P, Schwarze A et al. Development of hypoplastic left heart syndrome after diagnosis of aortic stenosis in the first trimester by early echocardiography. Ultrasound Obstet Gynecol 2006; 28: 106-109

26 Allan L. Left heart malformations. In: Yagel S, Silverman NH, Gembruch U (Hrsg). Fetal Cardiology. London: Martin Dunitz, 2003: 211-221
27 Berg C, Geipel A, Kamil D et al. The syndrome of left isomerism: sonographic findings and outcome in prenatally diagnosed cases. J Ultrasound Med 2005; 24: 921-931

28 Berg C, Geipel A, Kamil D et al. The syndrome of right isomerism-prenatal diagnosis and outcome. Ultraschall in Med 2006; 27: 225-233

29 Berg C, Bender F, Soukup M et al. Right aortic arch detected in fetal life. Ultrasound Obstet Gynecol 2006; 28: 882-889

30 Smrcek JM, Berg C, Geipel A et al. Early fetal echocardiography: heart biometry and visualization of cardiac structures between 10 and 15 weeks' gestation. J Ultrasound Med 2006; 25: 173-182

31 Atzei A, Gajewska K, Huggon IC et al. Relationship between nuchal translucency thickness and prevalence of major cardiac defects in fetuses with normal karyotype. Ultrasound Obstet Gynecol 2005; 26: 154-157

32 Huggon IC, Ghi T, Cook AC et al. Fetal cardiac abnormalities identified prior to 14 weeks' gestation. Ultrasound Obstet Gynecol 2002; 20: 22-29

33 Smrcek JM, Berg C, Geipel A et al. Detection rate of early fetal echocardiography and in utero development of congenital heart defects. J Ultrasound Med 2006; 25: 187-196

34 Becker R, Wegner RD. Detailed screening for fetal anomalies and cardiac defects at the 11-13-week scan. Ultrasound Obstet Gynecol 2006; 27: 613-618

35 Westin M, Saltvedt S, Bergman G et al. Routine ultrasound examination at 12 or 18 gestational weeks for prenatal detection of major congenital heart malformations? A randomised controlled trial comprising 36299 fetuses. BJOG 2006; 113: 675-682

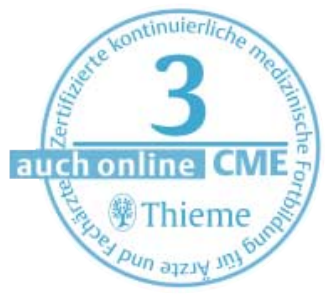




\section{CME-Fragen MC Prüfungsfragen}

1

Welche Prozentzahl von Herzfehlern ist unter optimalen

Voraussetzungen (gutes Ultraschallsystem und geschulter Untersucher, 20.-22. SSW) im Vier-Kammer-Blick erkennbar?

$10-20 \%$

$20-30 \%$

$40-50 \%$

$70-80 \%$

$90-100 \%$

Welche diagnostische Methode ist geeignet, fetale

Arrhythmien zu differenzieren?

Die Herzfrequenzkurve im Kardiotokogramm

Die B-Mode-Sonografie

Die 3-dimensionale Sonografie

Die M-Mode-Echokardiografie

Die Doppler-Untersuchung der Arteria umbilicalis

Was ist die häufigste Form der Arrhythmie beim Fetus?

Ventrikuläre Tachykardie

Vorhofflattern

Vorhofflimmern

AV-Block

Supraventrikuläre Extrasystolie

Welcher der folgenden Herzfehler wird bei einer Untersuchung des Vier-Kammer-Blickes im 2. Trimenon zumeist nicht erkannt?

Die Aortenatresie

Die Pulmonalatresie mit Ventrikelseptum-Defekt

Die Trikuspidalatresie

Die Ebstein'sche Anomalie

Der atrioventrikuläre Septum-Defekt

Welche der folgenden Aussagen ist falsch? Die Festlegung des abdominellen Situs als ersten Schritt bei der fetalen Echokardiografie empfiehlt sich, weil:

A sie einfach und schnell durchführbar ist.

B ohne Seitendifferenzierung keine sichere Beurteilung des fetalen Herzens erfolgen kann.

c Abweichungen vom Situs solitus wichtige Hinweiszeichen auf das Vorliegen kardialer Vitien sind.

D Dextrokardien häufig mit kardialen Vitien vergesellschaftet sind.

E der Situs solitus das Vorliegen kardialer Vitien weitestgehend ausschließt.

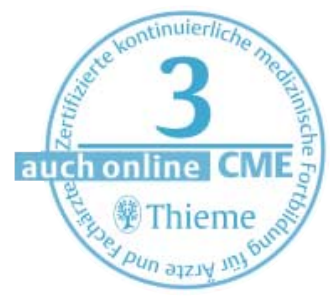

Welche Aussage zum Vier-Kammer-Blick trifft nicht zu?

$2 / 3$ des Herzens liegen in der linken Thoraxhälfte.

Der rechte Ventrikel trägt das Moderatorband.

Der linke Ventrikel ist spitzenbildend.

D Die Mitralklappe setzt weiter apikal am Ventrikelseptum an als die Trikuspidalklappe.

E Hinter dem Herz läuft nur ein größeres Gefäß links der Wirbelsäule (die Aorta descendens).

Welche Aussage zur Kardiomegalie trifft nicht zu? Sie tritt am ehesten auf im Rahmen von

Anämien.

AV-Malformationen.

Tachyarrhythmien.

Zwerchfellhernien.

feto-fetalen Transfusionssyndromen.

8 Welche Aussage zu fetalen kardialen Vitien trifft am wenigsten zu?

A Pulmonalstenosen bei Fallot'scher Tetralogie führen meist zu einer Hypoplasie des rechten Ventrikels.

B Ventrikelseptum-Defekte (mit atrioventrikulären SeptumDefekten) sind die am häufigsten diagnostizierten Vitien.

C Beim atrioventrikulären Septum-Defekt fällt in der Diastole das fehlende Herzkreuz auf.

D Die Ebstein'sche Anomalie ist häufig mit einer Kardiomegalie assoziiert.

E Die Trikuspidalatresie ist fast immer mit einem Ventrikelseptum-Defekt vergesellschaftet.

Pulmonal-Atresien sind meist mit einem Ventrikelseptum-Defekt assoziiert.

B Ein typischer Begleitbefund bei einer Pulmonalatresie mit intaktem Ventrikelseptum ist eine Mitralinsuffizienz.

c Aorten-Stenosen und -Atresien sind meist mit einem intakten Ventrikelseptum assoziiert.

D Der Truncus arteriosus communis fällt im Vier-Kammer-Blick nur auf, wenn er mit einem großen Ventrikelseptum-Defekt assoziiert ist.

E Mitralatresien ohne Ventrikelseptum-Defekt führen zum Bild des hypoplastischen Linksherzens.

Welche Aussage zur Echokardiografie im 1. Trimenon ist falsch?

A Die Farbdoppler-Echokardiografie erleichtert das Auffinden der großen Arterien.

B Eine Trikuspidalinsuffizienz im ersten Trimenon erhöht bei Feten mit erweiterter Nackentransparenz zusätzlich das Aneuploidierisiko und das Risiko für das Vorliegen kardialer Vitien.

C Die Untersuchung sollte grundsätzlich von transvaginal erfolgen.

D Im Hochrisikokollektiv und in Expertenhand werden ca. $60-70 \%$ aller Vitien im 1. Trimenon entdeckt.

E Der am häufigsten im 1. Trimenon diagnostizierte Herzfehler ist der atrioventrikuläre Septum-Defekt. 


\section{A Angaben zur Person} ankreuzen

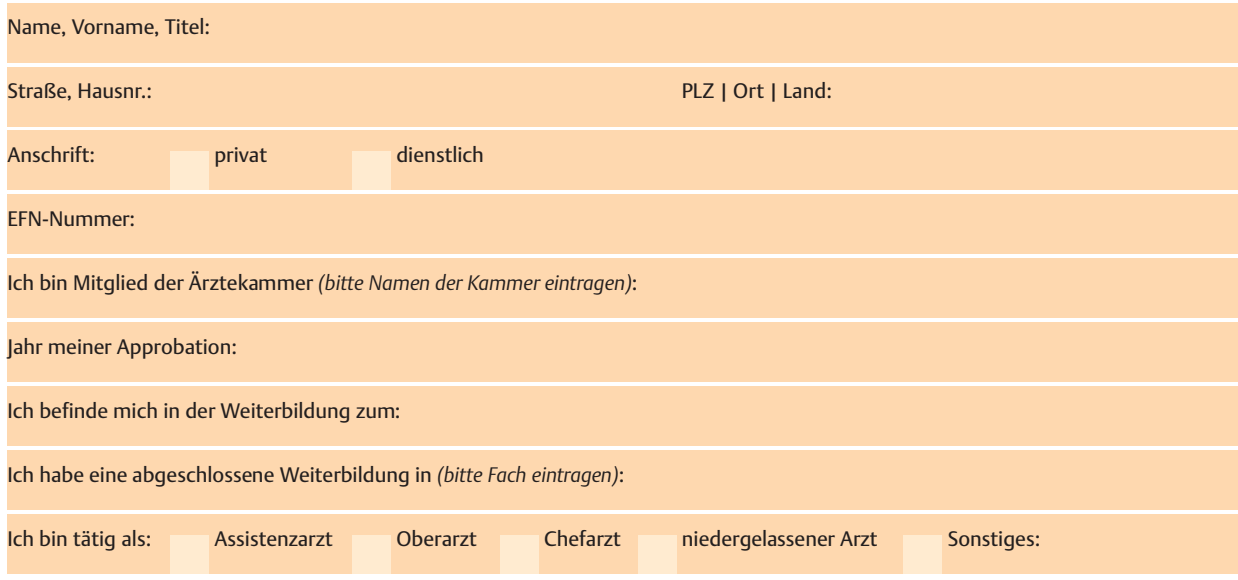

\section{B Lernerfolgskontrolle}

Bitte nur eine Antwort pro Frage

\section{1} 2 3 4 5
A $B$ C C D E

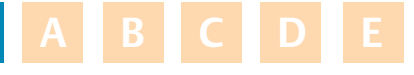

A B C C D

A B C C D E

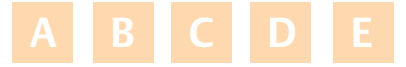

\section{6}

7

8

9

10

\section{Erklärung}

Ich versichere, dass ich die Beantwortung der Fragen selbst und ohne Hilfe durchgeführt habe

Ort | Datum: $\quad$ Unterschrift:

D Feld für Abonnement-Nummer

Bitte in dieses Feld Ihre Abonnement-Nummer eintragen: (siehe Adressaufkleber)

Zertifizierungsfeld (wird durch den Verlag ausgefüllt)
E Zertifizierungsfeld

Ihr Ergebnis

Sie haben von 10 Fragen richtig beantwortet.

Sie haben

bestanden und 3 CME-Punkte erworben.

nicht bestanden

Stuttgart, den

Datum

Stempel/Unterschrift

$>$ Teilnahme auch online möglich unter http://cme.thieme.de!

$>$ Bitte unbedingt Rückseite ausfüllen!

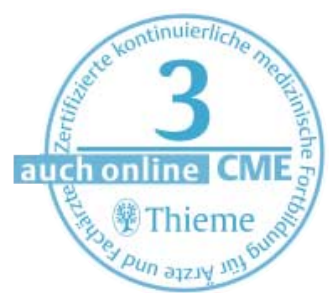


F Fragen zur Zertifizierung

Eine Antwort pro Frage. Bitte unbedingt ausfüllen bzw. ankreuzen, da die Evaluation sonst unvollständig ist!

\section{Didaktisch-methodische Evaluation}

1 Das Fortbildungsthema kommt in meiner ärztlichen Tätigkeit

häufig vor

regelmäßig vor

selten vor

gar nicht vor

2 Zum Fortbildungsthema habe ich

eine feste Gesamtstrategie

noch offene Einzelprobleme:

keine Strategie

3 Bezüglich des Fortbildungsthemas

fühle ich mich nach dem Studium des Beitrags in meiner Strategie bestätigt

habe ich meine Strategie verändert:

habe ich erstmals eine einheitliche Strategie erarbeitet

habe ich keine einheitliche Strategie erarbeiten können

4 Wurden aus der Sicht Ihrer täglichen Praxis heraus wichtige Aspekte des Themas nicht erwähnt?

zu knapp behandelt?

überbewertet

\begin{tabular}{|l|l|}
\hline ja welche \\
ja welche \\
\hline ja welche \\
\hline
\end{tabular}

5 Verständlichkeit des Beitrags

Der Beitrag ist nur für Spezialisten verständlich

Der Beitrag ist auch für Nicht-Spezialisten verständlich

6

Beantwortung der Fragen

Die Fragen lassen sich aus dem Studium des Beitrages allein beantworten

Die Fragen lassen sich nur unter Zuhilfenahme zusätzlicher Literatur beantworten

Die Aussagen des Beitrages benötigen eine ausführlichere Darstellung

zusätzlicher Daten

von Befunden bildgebender Verfahren

die Darstellung ist ausreichend

8 Wie viel Zeit haben Sie für das Lesen des Beitrages und die Bearbeitung des Quiz benötigt?

Bitte senden Sie den vollständigen Antwortbogen zusammen mit einem an Sie selbst adressierten und ausreichend frankierten Rückumschlag an den

Georg Thieme Verlag KG, Stichwort „CME“, Postfach 301120,70451 Stuttgart, Deutschland 


\section{CME-Questions The Four-Chamber View in Fetal Echocardiography}

1 What percentage of heart defects can be recognised in the four chamber view under optimal conditions (good sonographic equipment and highly trained examiner, $20^{\text {th }}$ $22^{\text {nd }}$ week of pregnancy)?

A $\quad 10-20 \%$

B $20-30 \%$

C $\quad 40-50 \%$

D $\quad 70-80 \%$

E $\quad 90-100 \%$

2 Which diagnostic method is suitable for the differential diagnosis of fetal arrhythmias?

Heart frequency curve in cardiotocogram

B mode sonography

3-dimensional sonography

M mode echocardiography

Doppler examination of the umbilical artery

3

What is the most common form of arrhythmia in fetuses?

Ventricular tachycardia

Atrial flutter

Atrial fibrillation

AV block

Supraventricular extrasystoles

4 Which of the following heart defects usually cannot be recognised by examination of the four-chamber view in the $2^{\text {nd }}$ trimester?

A Aortic atresia

B Pulmonary atresia with ventricular septal defect

C Tricuspid atresia

D Ebstein's anomaly

E Atrioventricular septum defect

5 Which of the following statements is wrong? Definition of the abdominal situs is recommended as the first step in fetal echocardiography because:

A It can be simply and rapidly performed.

B Without a differentiation of the sides a worthwhile evaluation of the fetal heart cannot be made.

c Deviations from the situs solitus are important signs for the presence of cardiac defects.

D Dextrocardias are frequently accompanied by cardiac defects.

E The situs solitus excludes more or less completely the presence of cardiac defects.

Which statement does not apply for the four-chamber

view?

$2 / 3$ of the heart lie in the left half of the thorax.

The right ventricle carries the moderator band.

The left ventricle forms the apex.

The mitral valve inserts further apical at the ventricular septum than the tricuspid valve.

E Behind the heart there is only one larger vessel to the left of the spinal column (the descending aorta).
7 Which statement does not apply to cardiomegaly? It coours most frequently in cases of

Anemias

AV malformations

Tachyarrhythmias

Diaphragmatic hernias

Twin-twin transfusion syndromes

8 Which statement is least applicable to fetal heart defects?

A Pulmonary stenoses in tetuses with technology of Tallot mostly lead to hypoplasia of the right ventricle

B Ventricular septal defects (including atrioventricular septal defects) are the most frequently diagnosed defects.

c In atrioventricular septal defect the absence of the "heart cross" is conspicuous in the diastole.

D Ebstein's anomaly is frequently associated with cardiomegaly.

E Tricuspid atresia is almost always accompanied by a ventricular septal defect.

A Pulmonary atresia is mostly associated with a ventricular septal defect.

B A typical incidental finding in pulmonary stensosis with an intact ventricular septum is a mitral insufficiency.

C Aortic stenoses and atresias are mostly ssociated with an intact ventricular septum.

D The common arterial trunk is only conspicuous in the fourchamber view when it is associated with a large ventricular septal defect.

E Mitral atresias without a ventricular septal defect lead to the picture of a hypoplastic left heart.

Which statement about echocardiography in the $1^{\text {st }}$ trimester is wrong?

A Colour Doppler echocardiography facilitates the detection of the great arteries.

B For fetuses with an increased nuchal translucency, a tricuspid insufficiency in the first trimester additionally increases the risk of aneuploidy and the risk for the presence of cardiac defects.

C The examination should principally be performed in the transvaginal technique.

D In high-risk collectives and in expert hands about $60-70 \%$ of all cardiac defects are detected in the $1^{\text {st }}$ trimester.

E The most frequently diagnosed heart defect in the $1^{\text {st }}$ trimester is the atrioventricular septal defect. 
A Personal data

Name, first name, degree or title:

Street, No.:
Cedex | City | Country:
Adress: $\quad$ private $\quad$ official

\section{B Learning effect check}

Check one answer

per question
1

2

3

4

5
1

3

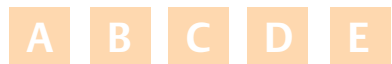

A $B$ B C D E

A $B$ C C D E

A B C D E

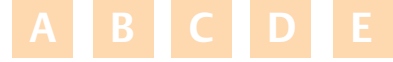

6

7

8

9

10
Space for Subscription No.

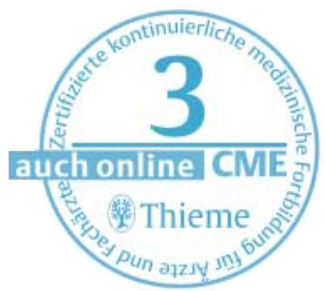

Please state your subscription No.:

(see address label)

Score (to be completed by the publishers)
E Space for certifying learning results Your score

You have answered of 10 questions correctly.

You have passed and have 3 CME points to your credit.

You have failed

Stuttgart

Date

Stamp/Signed
Important Note for readers outside Austria, Germany and Switzerland

At present, certification of the Continuing Medical Education features in Ultraschall in der Medizin is officially recognised by the German and Austrian medical associations and by the Swiss Ultrasound Society. Participants residing in other countries may please address their national medical association or their national specialist societies for recognition of their CME scores.

\section{Conditions of Participation in Certified Continuing Medical Education}

Participation is possible both via internet (http://cme.thieme.com) as well as by post.

For one Continuing Medical Education unit you will be credited with 3 Score points. To be awarded this score, the following conditions must be fulfilled:

- $70 \%$ of the questions must have been answered correctly

- The questions A to D of the CME reply form must be fully completed. Incomplete forms are not eligible!

- Your subscription number must be entered in the appropriate space on the above CME reply form.

Please participate online at http://cme.thieme.com or return the above CME reply form to the following address: Georg Thieme Verlag KG, keyword “CME”, P.O. Box 3011 20, 70451 Stuttgart, Germany.

Closing date: April 30, 2008 
Important Note for readers outside Austria, Germany and Switzerland

At present, certification of the Continuing Medical Education features in Ultraschall in der Medizin/European Journal of Ultrasound is officially recognised by the German and Austrian medical associations and by the Swiss Ultrasound Society. Participants residing in other countries may please address their national medical association or their national specialist societies for recognition of their CME scores. Participation is possible via Internet (http://cme.thieme.com) as well as by regular mail (see page 156).

\section{Was ist zertifizierte Fortbildung?}

Hinter der Abkürzung CME verbirgt sich „continuing medical education“, also kontinuierliche medizinische Fort- und Weiterbildung. Zur Dokumentation der kontinuierlichen Fortbildung der Ärzte wurde das Fortbildungszertifikat der Ärztekammern etabliert.

\section{Was ist eine Fortbildungseinheit?}

In den einheitlichen Bewertungskriterien der Bundesärztekammer ist festgelegt: „Die Grundeinheit der Fortbildungsaktivitäten ist der Fortbildungspunkt. Dieser entspricht in der Regel einer abgeschlossenen Fortbildungsstunde (45 Minuten).

\section{Anerkennung der CME-Beiträge}

Die Fortbildung in Ultraschall in der Medizin wurde von der Nordrheinischen Akademie für ärztliche Fort- und Weiterbildung für das Fortbildungszertifikat anerkannt, das heißt, die Vergabe der Punkte kann direkt durch die Thieme Verlagsgruppe erfolgen. Die Fortbildung in Ultraschall in der Medizin gehört zur Kategorie „strukturierte interaktive Fortbildung“. Entsprechend einer Absprache der Ärztekammern werden die von der Nordrheinischen Akademie für ärztliche Fort- und Weiterbildung anerkannten Fortbildungsveranstaltungen auch von den anderen zertifizierenden Ärztekammern anerkannt.

\section{Datenschutz}

Ihre Daten werden ausschließlich für die Bearbeitung dieser Fortbildungseinheit verwendet. Es erfolgt keine Speicherung der Ergebnisse über die für die Bearbeitung der Fortbildungseinheit notwendige Zeit hinaus. Die Daten werden nach Versand der Testate anonymisiert. Namens- und Adressangaben dienen nur dem Versand der Testate. Die Angaben zur Person dienen nur statistischen Zwecken und werden von den Adressangaben getrennt und anonymisiert verarbeitet.

\section{Wie kann ich teilnehmen?}

Jede Ärztin und jeder Arzt soll das Fortbildungszertifikat erlangen können. Deshalb ist die Teilnahme am CME-Programm von Ultra- schall in der Medizin nicht an ein Abonnement geknüpft! Die Teilnahme ist sowohl im Internet (http://cme.thieme.de) als auch postalisch möglich.

Im Internet muss man sich registrieren, wobei die Teilnahme an Fortbildungen abonnierter Zeitschriften ohne Zusatzkosten möglich ist. Alle Teilnehmer, die auf dem Postweg teilnehmen, benötigen für die Teilnahme den CMEBeitrag, den CME-Fragebogen, den CME-Antwortbogen, Briefumschläge und Briefmarken. Auch hier fallen bei Angabe der Abonummer für die Teilnahme keine zusätzliche Kosten an. Teilnehmer, die nicht Abonnenten von Ultraschall in der Medizin sind, können für die Internet-Teilnahme dort direkt ein Guthaben einrichten, von dem pro Teilnahme ein Unkostenbeitrag abgebucht wird.

\section{Für Teilnehmer in Österreich}

Die Fortbildungspunkte der Ultraschall in der Medizin werden gemäß der Novellierung der DFPRichtlinien vom 23.6.2005 (§26 Abs. 3) auch von den österreichischen Ärztekammern anerkannt.

Für Teilnehmer in der Schweiz

Die Fortbildungspunkte der Ultraschall in der Medizin werden gemäß der Richtlinien der SGUM/ SSUM anerkannt. Die Kontrolle der Fortbildung durch die SGUM/SSUM erfolgt im Auftrag der FMH (Foederation Medicorum Helveticorum) im Rahmen der Fortbildungsordnung.

\section{Teilnahmebedingungen der zertifizierten} Fortbildung

Für eine Fortbildungseinheit erhalten Sie 3 Fortbildungspunkte. Hierfür

- müssen $70 \%$ der Fragen richtig beantwortet sein.

- müssen die Fragen der Einheiten A bis D des CME-Antwortbogens vollständig ausgefüllt sein. Unvollständige Bögen können nicht berücksichtigt werden!

- muss Ihre Abonnentennummer im entsprechenden Feld des CME-Antwortbogens angegeben sein.

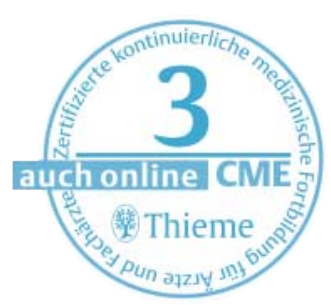

